Research Report No. 1/2006

\title{
Nothing New in the (North) East? Interpreting the Rhetoric and Reality of Japanese Corporate Governance
}

Luke R. Nottage

Follow this and additional works at: http:/ / digitalcommons.osgoode.yorku.ca/clpe

\section{Recommended Citation}

Nottage, Luke R., "Nothing New in the (North) East? Interpreting the Rhetoric and Reality of Japanese Corporate Governance" (2006). Comparative Research in Law \& Political Economy. Research Paper No. 1/2006.

http://digitalcommons.osgoode.yorku.ca/clpe/160 


\section{$\mathrm{C}^{\mathrm{P}} \mathrm{E}$}

\section{Law Research Institute Research Paper Series}

CLPE Research Paper 1/2006

Luke Nottage

Nothing New in the (North) East?

Interpreting the Rhetoric and Reality of

Japanese Corporate Governance

Keywords: corporate governance, comparative law, Japan

Dr. Luke Nottage

Co-Director, Australian Network for Japanese Law Email: luken@uow.edu.au

An index to the working papers in the Comparative Research in Law and Political Economy

Research Paper Series is located at:

http://www.comparativeresearch.net

CLPE RPS Editors: John Cioffi (University of California at Riverside),

Peer Zumbansen (Osgoode Hall Law School, Toronto, Director

Comparative Research in Law and Political Economy)

Production Editors: James Brink (Osgoode Hall Law School, Toronto) 
CLPE Research Paper 1/2006

Vol. 02 No. 01 (2006)

\title{
Luke Nottage
}

\section{NOTHING NEW IN THE (NORTH) EAST? INTERPRETING THE RHETORIC AND REALITY OF JAPANESE CORPORATE GOVERNANCE}

\begin{abstract}
Japan finally seems to be pulling itself out of its "lost decade" (and a half) of economic stagnation. Some grudgingly or triumphantly attribute this to micro-economic reforms, freeing up arthritic markets, although there is also evidence that macroeconomic policy failures have been a major cause of poor performance since the 1990s. Many point to overlapping transformations in corporate governance, broadly defined to cover relationships among managers and employees as well as between firms and outside shareholders, creditors, and other stakeholders. These relationships are in flux, with moves arguably favouring shareholders and more market-driven control mechanisms.
\end{abstract}

It has certainly been a "found decade" for law reform in Japan, particularly in corporate law, with a plethora of legislative amendments commencing around 1993 and culminating in the enactment of a consolidated "Company Law" in 2005. This "modernisation" project, particularly since 2001, is reportedly aimed at (i) securing better corporate governance; (ii) bringing the law into line with a highly-developed information society; (iii) liberalising fundraising measures; (iv) bringing corporate law into line with the internationalization of corporate activity; and (v) modernizing terms and consolidating corporate law. Because the suite of revisions has moved away from strict mandatory rules set out originally in Japan's Commercial Code of 1899, modeled primarily on German law, another growing perception is that Japanese corporate law and practice is or will soon be converging significantly on US models. 
However, assessments remain divided as to whether these moves in corporate governance and capitalism more generally in Japan amount to a new paradigm or "regime shift". Focusing primarily on quite influential commentary in English, Part I of this paper outlines two pairs of views. It concludes that the most plausible assessment is of significant but "gradual transformation" towards a more market-driven approach, evident also in other advanced political economies.

Drawing more generally from these often virulently divided views, Part II sets out five ways forward through the proliferating literature and source material on corporate governance in Japan. Particular care must be taken in: (i) selecting the temporal timeframe, (ii) selecting countries to compare, (iii) balancing blackletter law and broader socio-economic context, (iv) reflecting on and disclosing normative preferences, and $(\mathrm{v})$ giving weight to processes as well as outcomes, when assessing change in Japan and any other country's governance system.

Part III ends with a call for further research particularly on lawand policy-producing processes, rather than mainly outcomes. It also outlines the usefulness of this analytical framework for analysing the broader field of Corporate Social Responsibility, now emerging as the next major area of debate and transformation in Japan - as elsewhere.

Keywords: corporate governance, comparative law, Japan

Dr. Luke Nottage

Co-Director, Australian Network for Japanese Law

Email: luken@uow.edu.au 


\title{
NOTHING NeW IN THE (NORTH) EAST? INTERPRETING THE RHETORIC AND REALITY OF JAPANESE CORPORATE GOVERNANCE $^{\star}$
}

\author{
Dr Luke Nottage ${ }^{\#}$
}

\section{INTRODUCTION}

Japan has recently reappeared on the radar screen of comparative corporate governance debates, including in the writings of commentators in Australia. Two main reasons can be imagined for this renewed interest. One is contemporary concern about the perceived excesses of the Anglo-American model of corporate governance, focused on maximizing shareholder value, in the wake of widespread corporate collapses in the US and Australia. Japan has regained attention as promising a broader-based "stakeholder" model, giving weight also to the interests of core employees, creditors (especially the so-called "main banks"), key suppliers and customers (especially those in keiretsu corporate groups) \{Acquaah-Gaisie 2005: 43\}. Indeed, with the Australia-US Free Trade Agreement recently entering in force, fears of further excessive "Americanisation of Australian corporate law" (cf \{von

\footnotetext{
Paper for the Corporate Law Teachers Association conference, University of Queensland, 6-7 February 2006. The skeleton of this paper was presented at the inaugural International CLPE Conference, "The Corporate Governance Matrix: Unfolding the New Agenda", Osgoode Hall Law School, Toronto, 20-21 October 2005. Flesh was added to the bones at a seminar at the Centre for at the University of Wollongong, on 9 November 2005. I am grateful to the organizers and participants at these events, for the research assistance from Hitoshi Nasu, and for the support of the Australian Research Council (Discovery Grant A1753).

" Senior Lecturer, University of Sydney Faculty of Law; Co-Director, Australian Network for Japanese Law; luken@law.usyd.edu.au.
} 
Nessen 1999\}) have led to calls for Australia to contest convergence by drawing on stakeholder models reportedly more prevalent in our region, notably in Japan \{Clarke 2005: 118-29\}. This possibility is reinforced by the potential for a full-scale FTA between Australia and Japan, leveraging off the looser AustraliaJapan Trade and Economic Framework agreed upon in 2003.1 A second reason for greater interest recently in Japanese corporate governance is that its vast economy - still many times larger than China's, for example - seems finally to be pulling itself out of its "lost decade" (and a half) of economic stagnation. Indeed, the author of "Japan: The System that Soured" $\{$ Katz 1998\} now argues that it will stun the world in its economic renaissance, albeit probably not for another decade - following a "tumultuous battle" at the political level \{Katz 2003: 10\}.

However, some grudgingly or triumphantly attribute incipient economic revival precisely to Japan's micro-economic reforms in freeing up arthritic markets \{The Economist, 2005 \#190\}, although there is also good evidence that macro-economic policy failures were a major cause of poor economic performance since the 1990s \{Lincoln 2003\}. Relatedly, many highlight overlapping transformations in corporate governance towards greater primacy being accorded to shareholders and equity markets, noting for example declines in stable and cross-shareholdings, rapid growth in foreign shareholders, and more activism from Japanese institutional shareholders. In addition, it has certainly been a "found decade" for law reform in Japan, particularly in corporate law. A plethora of statutory amendments has been enacted, outlined in Appendix A2, commencing around 1993 and

\footnotetext{
${ }^{1}$ Both countries embarked in April 2005 on a formal feasibility study into a comprehensive FTA: see <http://www.dfat.gov.au/geo/japan/fta/index.html>. ${ }^{2}$ Details of many of these changes are provided in \{Nottage 2001\}, updated and developed in \{Nottage and Wolff 2005\} (both now available via www.ssrn.com), and given a more practical focus in \{Nottage and Wolff 2000-5\}. This paper also generally limits its literature references to works not cited in the former two publications, or in \{Nottage 2005b\}. There has been relatively fewer changes to
} 
culminating in the enactment of a consolidated "Companies Act" in 2005. The aims of this "modernisation" project, particularly over 2001-5, have been described as (i) securing better corporate governance; (ii) bringing the law into line with a highly-developed information society; (iii) liberalising fundraising measures; (iv) bringing corporate law into line with the internationalization of corporate activity; and $(\mathrm{v})$ modernizing terms and consolidating corporate law \{Takahashi and Shimizu 2005: 36\}. More generally, the reforms since 1993 include "substantial changes in board governance and incentive structures, major developments in the areas of directorial duties and personal liability, and expansions of organizational flexibility". This has been accompanied by Japanese corporate law norms with distinct parallels to Delaware law, especially regarding the use of defensive measures like "poison pills" in Japan's brave new world of occasional hostile takeovers \{Milhaupt 2005a: 2175\}. Because this package of reforms has relaxed many mandatory rules set out in Japan's Commercial Code, originally enacted in 1899 based primarily on German law \{Baum and Takahashi 2005\}, another growing perception is that Japanese corporate law and practice is or will soon be converging strongly on the US model \{cf Nottage and Wolff 2005\}.

Nonetheless, assessments remain divided as to whether these moves in corporate governance and capitalism more generally in Japan amount to a new paradigm or "regime shift" \{Pempel 1998\}. Part I of this paper introduces and critically assesses often influential commentary primarily in English on contemporary Japanese developments. 3 It identifies two pairs of views, stressing

securities regulation in Japan, but those have also been considerable \{Kelemen and Sibbitt 2002\}.

${ }^{3}$ This paper only touches on the literature in Japanese. One reason is that it is even vaster. It is also less likely to be accessible to most readers, and hence in need of an interpretive framework like that proposed here for the literature in English. In addition, the "world" of writings in Japanese, particularly in academic circles and even in the relatively new field of corporate governance, tends to focus somewhat more on black-letter law than how that is embedded in socio-economic context. This disjunction, also somewhat evident also in the 
respectively continuity and change, and argues that the perception of significant but "gradual transformation" - common also in other advanced political economies \{Streeck and Thelen eds 2005\} - is most plausible. This conclusion requires those who invoke Japan as still exemplifying a strong stakeholder model to concede that it continues to morph towards a more Anglo-American model; but it also identifies a resilient alternative to the latter, and thus contradicts "strong convergence" theorists (see also generally \{Hill 2005\}, reviewing \{Gordon and Roe eds 2004\}). More generally, Part II sets out five ways forward through the burgeoning literature and source material on corporate governance in Japan.4 When assessing change versus continuity, great care must be taken in: (i) selecting timeframes, (ii) selecting countries to compare, (iii) balancing black-letter law and broader socio-economic context, (iv) reflecting on and disclosing normative preferences, and $(\mathrm{v})$ giving weight to processes as well as outcomes. These lessons can also be extended to broader comparative corporate governance research, which may be settling into somewhat of a rut (cf generally \{Denis and McConnell 2005\}; \{Pinto 2005\}). Part III of the paper reviews these conclusions and ends with a call for further research particularly on law- and policy-producing processes, rather than just outcomes. It also sketches how such lessons may be useful in comparing Japanese developments in the overlapping but even broader field of Corporate Social Responsibility (CSR). Overall, therefore, this paper aims both to offer a roadmap through the burgeoning literature on corporate governance and capitalism more generally in Japan; but also to engage with and contribute to ongoing theory-building in broader comparative studies in these fields, emerging from a variety of disciplines - particularly law, economics, politics, and sociology.

literature in German (see eg \{Dernauer 2005\}), may lead to somewhat different assessments of continuity versus change (\{Ginsburg et al 2001\}), as suggested in Part II(iii) below.

${ }^{4}$ A rich data source on unfolding events in Japan is the monthly e-mail bulletin freely available via http://www.law.usyd.edu.au/anjel/content/anjel research guide.htm. 


\section{CHANGE IN JAPANESE SOCIETY, LAW AND CORPORATE GOVERNANCE: TWO TIMES TWO VIEWS}

The first set of views shares a perception of no or minimal change in Japan, but each view differs on the immutable nature of its socio-economic ordering and legal system. The second set, by contrast, acknowledges significant change; but one view argues that a radical shift is evident or underway, whereas another perceives a more gradual transformation.

\section{(I) NO OR MINIMAL CHANGE: (A) STILL COMMUNITARIAN SOCIETY \& STAKEHOLDER GOVERNANCE}

At one extreme, John Haley $\{2005 a ; 2005 b\}$ insists that nothing is new in the (North) East, in that the corporate sector - like the public sector5 - continues to give primacy to entry-level hiring coupled with a central personnel office staffed by senior career managers charged with recruitment, training, assignment and promotion of career staff. In his view, this underpins a broader stakeholder approach to corporate governance, and fits with Japan's ongoing communitarian approach to law and society \{Haley 1998\}.

Ronald \{Dore 2000\} has become more circumspect, conceding that "employee sovereignty has shifted markedly towards shareholder sovereignty", and identifying as another related pressure point "the development of a market for corporate control" \{Dore 2005: 443\}. But he too emphasizes that employment institutions

\footnotetext{
${ }^{5} \mathrm{Cf}$ eg $\{$ Amyx 2004\}, noting mid-career hires of specialists into the Financial Supervisory Agency set up in 1998 ("FSA", expanded into the Financial Services Agency in 2000), as the centerpiece of a novel regime for financial markets regulation following turmoil in financial markets particularly from late 1997; and of mid-career transfers and hires of specialists into the Cabinet Office, increasingly powerful since its inauguration in 2001.
} 
affecting the careers of top managers, in particular, have still changed little in Japan, even compared to Germany. This helps to insulate Japan's traditional means of motivating both honest and dynamic corporate managers, despite the fading ideology encouraging trust-based relationships that had more directly underpinned such institutions.6

Sanford \{Jacoby 2005: 11-12\}, similarly drawing primarily on empirical research from around 2001, also concludes that a core aspect of corporate governance has not changed much since around 1980, at least for listed companies and compared to the US. He argues that Japanese companies remain relatively organizationoriented, focused on long-term employees and broader stakeholders in their corporate governance, underscored by a highstatus centralised Human Relations (HR) department. Compared to Haley (who implies that the distribution of Japanese firms in 2004, "Japan 2004" in Figure 1 below, remains virtually identical to that in 1980), Jacoby concedes some shifts toward more marketoriented firms, with HR executives losing some influence. However, he views the US as having moved even more strongly towards that extreme (from "US 1980" to "US 2004") over the last two decades.

Figure 1 (adapted from \{Jacoby 2005: 158\})

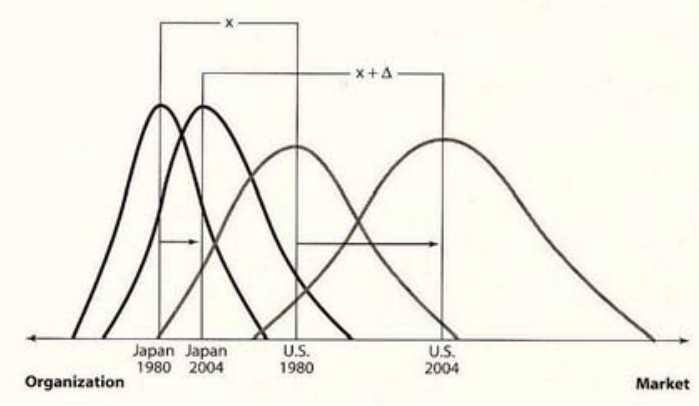

${ }^{6}$ Thus, the neo-communitarian hermeneutical approach to Japanese law and society presented by \{Tanase, 2005; forthcoming\} has rather more in common with Dore. 
Although Jacoby's study purports to be about "corporate governance", he focuses overwhelmingly on "employment relations". Admittedly, especially in the Japanese context, the relations between managers and employees are very important for the governance of firms. But so too are other relations that he hardly touches on, particularly between the firms and their creditors or suppliers. Nonetheless, Figure 1 can be thought also as illustrating only a limited shift in Japan (" $\mathrm{x}$ ") away from a broader stakeholder-based approach to corporate governance overall and towards a more shareholder-based approach, which moreover has gained even more traction in the US over the last quarter century $(" \mathrm{x}+\bullet ")$.

\section{(I) NO CHANGE: (B) ACTUALLY RATIONALLY SELF-INTERESTED, HENCE SHAREHOLDER PRIMACY}

In partial contrast, Mark Ramseyer agrees that little has really changed in Japan, but only because everyone else has fundamentally misconstrued the true nature of its law and society. Rather than a communitarian orientation and broader stakeholder primacy, he asserts, the Japanese have always been driven by narrow (mostly financial) rational self-interest (Ramseyer and Nakazoto 1999\}. This is reflected in more indirect but significant returns to shareholders even during the high-growth era after World War II, when "lifelong employment" practices spread among larger Japanese companies \{Kaplan and Ramseyer 1996\}. On this view, observed shifts towards greater shareholder primacy in recent years are merely a move "back to the future" of corporate law in Japan (\{Miwa and Ramseyer 2005a\}; cf also \{Okazaki 2004\}). Consistently, moreover, he and his main co-author insist that the "main banks" commonly perceived as having emerged as another substitute monitor of managerial performance were a figment of the (mainly Marxist) imagination \{Miwa \& Ramseyer 2005b\}. 
Thus, reports of their steady demise recently are wrong; they never existed.7 Ramseyer has not (yet) been bold enough to say that lifelong employment is also a pure fiction, but presumably he would decry this as a practice forced upon managers by a misguided legal system.

To visualize this understanding, think again of Figure 1 above as more generally depicting a spectrum of stakeholder versus shareholder corporate governance, as well as organization- versus market-oriented HR practices. Then, for Ramseyer, the two bell curves in Figure 1 above representing the distribution of Japanese firms in 1980 and 2004 ("Japan 1980" and "Japan 2004") may simply vanish, becoming their US counterparts ("US 1980" and "US 2004")! Alternatively, at least, the curves need to be redrawn similarly towards the market end of the spectrum.

\section{(II) Change: (A) DRAMATIC SHIFTS TOWARDS MARKET SOLUTIONS AND SHAREHOLDER PRIMACY}

A major contrast lies with those who instead perceive significant shifts occurring in Japan, away from a stakeholder approach to corporate governance giving primacy especially to core employees and instead giving primacy to shareholder interests. Again there

\footnotetext{
${ }^{7}$ Cf eg \{Milhaupt 2002\}, summarised in \{Nottage 2005b\} with other literature contrary to Ramseyer's assertions. For more empirical evidence of the post-War importance of main banks, see also eg \{Amyx 2004\} (demonstrating their compatibility with informal regulation by the Ministry of Finance until the establishment of the FSA in 1998: agreeing on the latter, see also \{Cerny 2005\}); and especially \{Gerlach and Lincoln 2004\} (using qualitative and quantitative analysis in chapter 3 , and regression analysis in chapter 4 , to demonstrate the partial persistence of main bank-centred "horizontal keiretsu", as well as manufacturing or distribution "vertical keiretsu"). For a sociological (rather than political science or economic) theory of Japan's banking networks, including an explanation for institutional and structural properties leading to superior bank performance when the economy was growing but poor performance as it has declined, see the social exchange model in \{Wan et al $2005\}$.
} 
are two variants. One view emphasises dramatic change, epitomized by the editor of The Economist in a recent comment on the appointment of a Welshman to head Sony, but also shared by many writers in the (especially Western) financial press:8

"Think of all the features that, 10, 15 or 20 years ago, were considered axiomatic about big Japanese companies. They had extensive cross-shareholdings with other firms, especially suppliers and banks. They used the promise of lifetime employment to keep their labor force loyal, paying according to age and seniority. They had strangely large corporate boards, stuffed with grandees and retired executives. They worried about sales and market share, not profits. Their top executives all came from within, and behaved more like bureaucrats taking their turn in the top seats for a few years than like corporate chieftains. The idea of foreigners on the board, let alone in senior management, was anathema.

Such generalizations were always a bit overdone, but not by much. Now, you can cross out every single one of them. Cross-shareholdings have largely been unwound. Lifetime employment, even in big firms, is now the exception not the rule thanks to changes in labor laws that have allowed workers to be employed on short-term contracts. Such employees make up $40 \%$ or more of the total at manufacturers such as Toyota. Many -- though not all -- corporate boards have been streamlined, with more independent directors and fewer placemen. The profitability of big Japanese firms has risen to record levels (when measured as a ratio to sales), thanks to restructuring,

${ }^{8}$ Emmott 2005\}. See also \{Dawson and Tashiro 2005\}. Emphasising the decline of cross-shareholding since the late 1990s, but hardly its complete "unwinding", see also \{Okabe 2002\}. 
the aforementioned labor-force changes, and efforts to fatten margins. Falling wages leave Japan's domestic economy still suffering from deflation and weak demand, but do wonders for corporate profits.

Executives remain primarily bureaucratic but there are now many more exceptions, sounding and behaving more like American CEOs and with senior management pay geared to performance. And foreign executives are no longer unacceptable."

Likewise, The Economist saw the victory of the Liberal Democratic Party (LDP) in the snap election it called on (symbolically) 11 September 2005, to renew overwhelmingly its mandate for deregulation of the postal savings system, as an important further step towards restoring Japan as "a normal advanced economy", as well as an indicator of "just how much the electorate has changed, and matured, over the course of Japan's dismal decade". 9

Similar views, of Japan and its corporate world well on the road to Americanisation, are also popular among other writers in the financial press.10 Again, it may be helpful to conceptualise such conclusions in terms of Figure 1. Even in employment relations, for example, The Economist would perceive a sharper shift by Japan towards the market end of the spectrum in recent years. Broadening the scope of corporate governance to encompass other relationships such as those between firms and their financial institutions, more clearly reconfigured after financial markets

\footnotetext{
${ }^{9}$ \{Economist, $2005 \# 139$ \}. But see the Leader in the same issue, concluding that the LDP's moderate reformism belies "a new Japan": \{Economist, 2005 \#139\}.

${ }^{10}$ See also eg \{Tett 2004\}. Apart from the obvious point that proclaiming "change" will tend to sell more copy than "continuity", this tendency in the financial press may be linked to broader shifts in the media world that have underpinned perceptions of crises and hence hence widespread changes in both government regulation and tort litigation in countries like the US \{Haltom and McCann 2004\}.
} 
crises and deregulation in the late 1990s, The Economist would argue for an even sharper shift towards more shareholder-driven corporate governance in Japan.

\section{(II) Change: (B) Significant SHIFTS AWAY FROM THE STAKEHOLDER MODEL}

The second variant of the perspective acknowledging more change, well underway in Japanese corporate governance and society, is more guarded. My own analyses so far have acknowledged a significant realignment of stakeholders, with shareholders winning out clearly over creditors, 11 but less so vis-à-vis employees (despite much more change underway than acknowledged by Haley12), and perhaps even less so in some areas of industrial organization (especially in relations with key suppliers) and relations between firms and regulators or the broader community (such as NGOs):

\footnotetext{
${ }^{11}$ For further instances of growing shareholder influence, not otherwise cited in this presentation, see eg $\{, 2005 \# 12\}$, $\{$ Hutton, 2005 \#62\}, \{Jopson, 2004 \#86\}, \{Sanchanta, 2005 \#74;Sapsford, 2005 \#77\}.

${ }^{12}$ Particularly on core incumbents in larger firms, see also \{Jacoby, 2005 \#95;Jacoby, 2005 \#73;Jacoby, 2005 \#72\} and (albeit generally with less change compared even to Germany) \{Jackson 2005; Jackson and Moerke 2005\}. But the proportion of non-regular employees has been rising disturbingly, from 20 to 30 percent over the last decade, despite rising unemployment and recession, and Japan faces the broader challenge of a rapidly graying population \{Seike 2005\}. The country also has an ever-increasing "lost generation" of young people who cannot and/or do not want to participate in the regular workforce based on the model extolled by Haley: see \{Mathews, 2004 \#167\}, \{Saito, 2005 \#21\} and \{Kondo, 2005 \#20\}.
} 
Figure 2 (from \{Nottage \& Wolff 2005\})

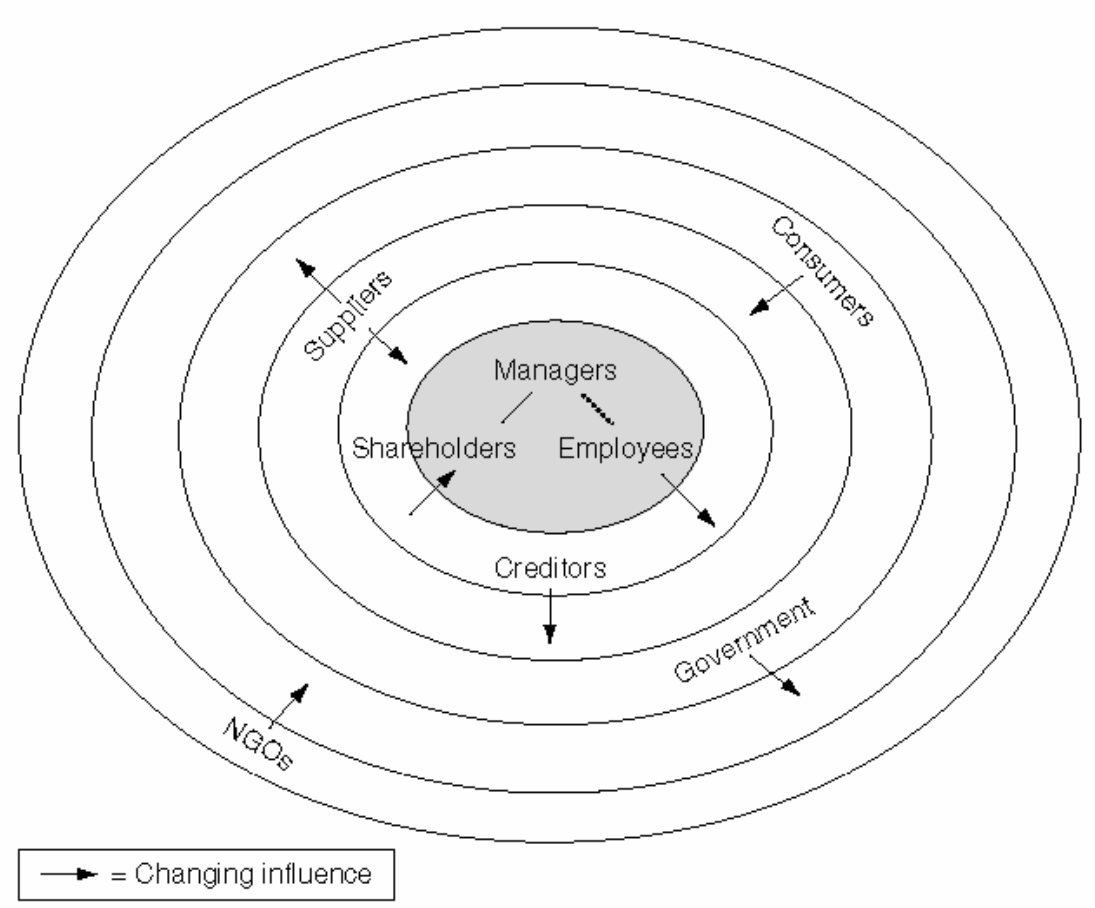

Relative stasis in the latter dimensions represents more than institutional inertia, and a multi-layered outcome \{Sarra and Nakahigashi 2002\} that poses problems for overly monolithic views of divergent "varieties of capitalism" (\{Nottage 2001; cf \{Hall \& Soskice 2001\} and \{Goodin 2003\}\}. It also means the continued existence of a competing ideological model for (reJorganizing corporate governance, allowing more trust-building "learning by monitoring" that may yet resonate in areas such as shareholder relations where the emerging ideology instead mostly assumes a "trust-defying" homo economicus. 13

${ }^{13}$ Cf eg \{Learmount 2002\}, contrasting "economic" theories of the firm assuming strongly self-interested human behaviour and "organizational" theories allowing for more other-oriented behaviour; but concluding from detailed qualitative studies that corporate governance relationships for Japanese 
Likewise, \{Lincoln and Gerlach 2004: 373$\}$ confirm that a new economy is emerging in Japan, differing from the old in significant ways. In their network analysis terms:

"it is characterized by weaker, less concatenated, less expansive, less multiplex and less embedded ties; more fleeting fragmented, asymmetric and numerous ties. The proposed reforms in Japanese corporate boards illustrate [as enacted in 2002 and in force since 2003 (see Appendix A), discussed below in relation to \{Gilson and Milhaupt 2005\}]. A board with a larger percentage of bona fide outsiders means more links between the firm and its environment but, absent the power of keiretsu to mold them, such ties will be less overlapping, interwoven and otherwise ordered than in the past. Although our data [primarily from the 1960s through to the 1990s] show it proceeding in fits and starts depending on the period and the group, the slow and uneven dissolution of the keiretsu is an inescapable macro-trend. In their stead is materializing a looser, more flexibly structured amalgam of micronetwork pairings and clusterings pegged closely to the strategic business goals of individual firms. However, much of the basis for the networks of the past persists:

firms overall - not just relationships with employees or senior managers, and even while changing somewhat - still fit better the latter theories. (He does not examine relationships with key suppliers, which retain elements of both economic and organizational theories.) Thus, his general perception tends more towards those of Dore and Jacoby. Albeit without addressing ideological underpinnings or implications, \{Hasegawa 2005: 216-7\} adopts a similar view. He concludes that the 1990s led only to "redefined internal" employee corporate governance, rationalizing board membership in a lower growth era, rather than "external" governance (involving more market-oriented mechanisms, for the benefit primarily of shareholders). More generally, drawing on studies from social psychology research into trust-based behaviour, see eg \{Blair and Stout 2001\} and related studies by them and others, reviewed in $\{\mathrm{Du}$ Plessis et al 2005: 374-81\}. 
companies still make strategic and symbolic investments in one another and favor long-term, hightrust partnerships over short-term arm's-length ties".

More specifically, \{Ahmadjian and Robbins 2005\} find that rising foreign ownership of listed Japanese companies over 1991-2000 led to significant downsizing even of permanent employees as well as asset divestitures, associated with a shift towards shareholderoriented corporate governance. However, the effects were less in firms more deeply embedded in the Japanese stakeholder system, namely with high levels of ownership by domestic financial institutions or close ties with other firms. AAhmadjian and Robbins 2005: 467-8\} then speculate that "restructuring among foreign-owned firms may remove the perceived illegitimacy of these practices and encourage their spread to larger, older and more prestigious firms", while conceding the alternative possibility of banks and business groups continuing "to check foreign influence, leading to an increased bifurcation between firms exposed to foreign capital that adopt Anglo-American practices and those that remain tied to the Japanese system and maintain business as usual". Quite consistently, \{Abe and Shimizutani 2005\} find that the rising numbers of outside directors in Japanese firms are more inclined to implement layoffs and voluntary or early retirement, while insiders are more likely to decrease new hiring and protect incumbent employees.

Curtis Milhaupt and Mark West, prolific commentators on corporate governance transformations in Japan, generally conclude that even more significant shifts are already underway in Japan. Most of their work, conveniently brought together in a recent collection of their essays \{Milhaupt and West 2004\}, has focused on how Japanese economic and political actors have reacted quite rationally and predictably to the evolving formal (legal) and informal (other institutional) "rules of the game". Thus, derivative suits against directors by shareholders to safeguard their interests were prohibitively expensive and therefore almost unheard of, until the filing fee was dropped to a small set amount by reform to the Commercial Code in 1993 (originally (West 1994; 2001b\}). The 
regime also had to be reconfigured in an attempt to develop a new market for venture capital \{Milhaupt 1997\}. Such shifts towards more shareholder-focused corporate governance were necessitated by the breakdown in Japan's "convoy" system of banking and finance, whereby financial institutions moved at the speed of the slowest member supported by the implicit guarantee of government bailouts, beginning with the housing mortgage debacle over the first half of the 1990s \{Milhaupt and Miller 1997\}; and crowned by the full-blown banking crisis of 1998 (see also \{Milhaupt 1999\}). Before such transformations, shareholders needed to turn to organized crime syndicates to partially secure their investments \{West 1999; Milhaupt and West 2000\}. Now, with new rules of the game leading also to a slowly growing market for Mergers \& Acquisitions (\{Milhaupt and West 2003a\}; see also (Milhaupt 2005a\}), even the new generation of Japan's elite - graduates of Tokyo University Law Faculty - are forsaking longterm careers in key ministries in favour of rapidly expanding and increasingly specialized Tokyo law firms (\{Milhaupt and West 2003b\}). Overall, they suggest that these studies indicate a shift from more informal to more formal rules or institutions.

However, this side of the equation - why and how the rules of the game change, thus influencing new patterns of observed behaviour - remains less closely examined. Although \{Milhaupt and West 2004\} acknowledge their debt to this prominent political economist, this collection of their works does not pursue the conceptualisation of rules or institutions as "endogenous rules of the game" advanced by \{Aoki 2001\}. On that view, institutions both arise from the interaction and stable expectations of socioeconomic actors (being a dependent variable at time $t$ ), but also guide and constrain actor behaviour (becoming an independent variable at time $t+1$ ) \{Amyx 2004: 27\}. Recent work by political economists comparing key components of Japanese corporate governance has also been sensitive to such feedback loops, even 
though it further complicates especially the quantitative analysis of causal patterns in historical development.14

Writing on his own \{Milhaupt 2001\} has emphasized the role of "norm entrepreneurs", eg in breaking an (informal) taboo against hostile takeovers under the new (legal and social) rules of the games, and the activities of such actors have certainly attracted growing attention in more recent years.15 Yet he has only just started to look at drivers of these new rules, especially the more formal (legal) ones that have been more prominent than the informal ones, but which (on their book's preliminary analysis) should tend to become more significant. For example, \{Kanda and Milhaupt 2003\} first point out that the director's duty of loyalty transplanted into the Commercial Code (Art 254-3) from the US in 1950 only became operational from the late 1980s. They then explain the initial stasis by the existence of partial substitutes (Art 254(3)'s duty of care), but also a lack of "micro-fit" (few avenues for derivative suits until 1993, and judges and lawyers capable of applying broad principles rather than narrow rules16) and weak

\footnotetext{
${ }^{14}$ For example \{Gourevitch and Shinn 2005: 16 and 23\} argue that "politics" such as electoral rules impact on "policies", such as minority shareholder protections, which in turn result in shareholder diffusion (a key corporate governance "outcome"); but also that a "policy generates support for its continuance by eliminating its opponents and strengthening its beneficiaries and their commitment to the policy", creating a feedback loop from outcomes back to politics. \{Thelen 2004: 290-1\} is even less deterministic, suggesting in particular that the German evolution of employment skills system since the late $19^{\text {th }}$ century shows how institutional complementarities can develop not just through positive feedback, but by actors actively adapting inherited institutions to new circumstances, interests or power constellations.

${ }^{15}$ See $\{$ Milhaupt 2005a\}; and also \{Economist.Intelligence.Unit, 2005 \#168\}, full report at http://www.eiu.com/MA Japan.

${ }^{16}$ The former seems more important than the latter, since Japanese legal practitioners have had few difficulties developing broad principles in other areas of law (such as "good faith" in contract law), and a relative aversion to brightline rules is consistent with the orientation of Japanese (and indeed US) law and legal institutions towards more substantive legal reasoning, at least compared to the English law tradition (\{Nottage 2002\}).
} 
"macro-fit" (private substitutes, such as crime syndicates, and lifetime employment practices in a high growth economy). Presumably, such factors should work towards the enactment of new rules, not just the sudden operationalisation of dormant "law in books". Instead, \{Milhaupt 2003\} indicates that a major determinant of corporate law changes over the last decade has been the growing power of Japan's managers and their lobbyists, since so many are enabling rules providing extra flexibility (see also Appendix A17). Such provisions can be used for the benefit of shareholders and the company as a whole, but also to insulate managers themselves (as we now know so well in the aftermath of Enron and its parallels in Australia: \{Clarke, 2003 \#105\}).

That view means acknowledging also that the politics of corporate law reform may be very context-specific, which is one lesson I draw from his most recent work on the effects of the "elective" corporate governance reforms enacted in 2002. His main focus is on how and why a small but significant number of listed large companies have elected to replace the German-inspired regime of statutory auditors monitoring the board of directors, in turn potentially monitoring managers in the interests of shareholders (but also possibly other stakeholders), with a "US-style" regime of Committees of (mostly outside) directors charged with Nomination, Compensation and Audit of directors. GGilson and Milhaupt 2005\} find a variety of firms and reasons for adopting this new alternative, ranging from signaling "good governance" (especially if major firms with significant foreign ownership, like Sony18) to, conversely, using the narrow definition -- so far19 -- of "outside" director to plant parent or sibling company directors on

\footnotetext{
${ }^{17}$ This updates \{Fujita 2004\}, drawing also on \{Takahashi and Shimizu 2005\} and \{Dernauer 2005\}. On earlier legislation, see Tatsuta 2005\} and especially \{Baum and Takahashi 2005\}.

${ }^{18}$ See also generally \{Ahmadjian 2005\}.

${ }^{19} \mathrm{Cf}$ already the tighter definition, requiring in fact "independence" and thus excluding parent company directors, expected even by Japan's Pension Fund Association: $\{$ Seki 2005\}.
} 
the new Committees in order to increase control of a corporate group (like Hitachi - with clear parallels with orthodox German, rather than Anglo-American, corporate practice). Interestingly, however, \{Milhaupt 2005b\} links this hybrid outcome to the lack of clear vision by policy-makers as to which of the two options was preferred, in turn due to a contest between the Ministry of Justice (MoJ) and the Ministry of Finance (MoF). The former initially proposed simply one, Committee-based corporate governance model; but the latter supposedly objected on behalf of the business community. Main reasons given by MoF were problems in securing requisite independent directors, and expecting them to operate in still highly relational networks. But another reason, reportedly, was the objection to imposing one corporate governance form on diverse organizations. Actually, this objection was echoed by the Ministry of Economy, Trade and Industry (METI: \{Ahmadjian 2003\}). Since the latter is even more closely linked to business sector lobby groups, the "success" in allowing two options in the 2002 Code amendments seems to reinforce the hypothesis of Milhaupt $\{2003\}$ about their growing political clout in corporate law reforms. On the other hand, it is very intriguing - and a departure from the old ways of reforming corporate law until the 1990s - that so many new players are involved in this policy-making process. The MoJ (traditionally charged with commercial law reform) now competes with METI (responsible for broader industrial policy) and MoF (bolstered by its jurisdiction over stock exchanges, which in other countries set such "elective" standards - often more strongly: see eg \{Collett and Hrasky 2005\}). In the background, but surfacing sometimes in the reform councils (shingikai) or committees in each of the ministries, or promoting a growing number of law reforms through private members' bills, we find the pro-business LDP Subcommittee on Commercial Law \{Fujita 2004\} and the Keidanren (\{Vogel 2005: 160\}; see generally also \{Kitagawa \& Nottage 2005\}). The battles, moreover, are fought out in the context of much greater media interest in corporate affairs and policy reform. 
In another recent study, into the evolving regulatory regime for hostile takeovers in Japan, \{Milhaupt 2005a\} highlights a new player in generating the new rules of the game: the courts. In Nippon Hoso KK v Livedoor KK (23 March 2005), the Tokyo High Court affirmed the trial court's injunction preventing the target broadcaster issuing warrants to thwart a hostile takeover by an internet provider led by a flamboyant young businessman and "norm entrepreneur", Takafumi Horie. The High Court clearly drew on the Delaware courts' approach developed in the Unocal case, focusing on the threat of target shareholder exploitation and the proportionality of the response by the target's management. A "Corporate Value Study Group" set up by METI in August 2004 then rushed to complete "Guidelines for Hostile Takeover Defensive Measures (Corporate Value Protection Measures", jointly issued with the MoJ in May 2005 based on the Study's Group report that drew even more heavily on Delaware law. On 1 June 2005, expressly referring to the Guidelines, the Tokyo District Court allowed a foreign institutional investor's challenge to Japan's first "poison pill". The Delaware model has thus provided a compromise "global standard", more shareholderoriented than the 2002 German Takeover Code implicitly rejected by the Study Group, but less so than the UK's City Code requiring target firm boards to remain strictly neutral and obtain shareholder approval before installing defensive measures. Yet, rather than outright Americanisation of Japanese law, \{Milhaupt 2005a: 2210-1\} suggests that "the High Court's decision could be the foundation for development of a Unocal rule with Japanese characteristics - preventing egregious entrenchment attempts by incumbent management, but sanctioning airtight defenses to protect a range of corporate interests that appear very broad from a U.S. perspective".

Indeed, the outcome in the Livedoor case in 2004, and that in the District Court case in 2005, suggest that Japanese courts are quite finely attuned to the "gradual transformation" of Japanese corporate governance towards a more shareholder-oriented - yet still stakeholder - model. If that transformation proceeds fairly clearly, we may expect further decisions along these lines, perhaps 
impacting back on legislative reform in this area or related fields of corporate law. Japanese courts have seen an upsurge in corporate law cases of many kinds since the 1990s (see eg \{Takahashi and Sakamoto 2004\}; (NichibenrenHomukenkyuZaidan ed 2004\}), creating more scope for further iterations of judicial innovation and legislative reform, as witnessed for example in the field of product liability over the last decade.20 Broader comparative analogies could be made with new interactions between the two spheres in contemporary corporate governance in Australia \{Corbett and Bottomley 2004\}, and even more elaborate processes of "reflexive harmonisation" in member states of the European Union adjusting their domestic takeover regimes in the shadow of a Directive finally enacted in 2004 \{Zumbansen 2004\}.

Overall, this new direction in Milhaupt's work, starting to address why and how (especially formal) legal rules are created rather than just their impact on corporate behaviour, seems to go against recent work by West. He argues that Japan's corporate law reforms, even since the 1990s, are driven by accelerating "exogenous" shocks such as scandals and (increasingly) foreign competition and economic downturn. \{West 2001\} contrasts this with "endogenous" change, led by rent-seeking actors (notably lawyers and other lobbyists in the US, with more scope for action given jurisdictional competition between Delaware and other states interested in attracting incorporations through corporate law reforms). In Japan recently, however, accounts by Milhaupt and others instead indicate growing "endogenous" competition and perhaps even more broadly reasoned dialogue - among a growing array of state and even non-state actors. 21 West's more

\footnotetext{
${ }^{20}$ In its judgment in early 1994 in the "exploding TV" case, the Osaka District Court pushed the legislature towards adding that year a strict liability cause of action for defective products \{Nottage 2004\}, and that legislation in turn seems to have been taken as a cue to issue pro-plaintiff judgments particularly since the late 1990s \{Nottage 2005\}, amidst renewed widespread concern for product safety.

${ }^{21}$ It remains true that even Japan's rapidly growing commercial law firms,
} 
recent work with \{Pistor et al 2003a; 2003b\} may be more suggestive especially for the current and foreseeable rounds of corporate law reform in Japan. In particular, it does seem likely that the more enabling Japanese corporate law continues to become, the more legal innovation will take place, and the greater the need will become for institutional innovation, including new law enforcement agents. Even under that model, however, the hybrid development under the 2002 reform makes it more doubtful that Japan, as a (perhaps unusually developed) "legal transplant country", will continue to reveal less innovative capacity as measured by the authors' rate of legal change in corporate law and finance.

\section{(III) “The Gradual Transformation": Beyond CONTINUITY, IN JAPAN AND BEYOND}

How should we assess then these very different answers to the question of whether there has been significant change in Japan and its corporate governance system, namely: (i) No, because Japan remains (a) communitarian or instead (b) individualistic in basic orientation, or (ii) Yes, (a) to a very large extent or (b) to a considerably lesser extent. In particular, can we see already or expect soon the "Americanisation of Japanese law", or at least important parts such as securities regulation, driven more broadly by economic liberalization, political fragmentation, and concomitant rise in the markets for legal services \{Kelemen and Sibbitt 2002\}? Readers should really be the judges, checking these commentators' selections of topics, their sources and data, and other material, including if possible the much vaster literature in Japanese.

\{Nagashima and Zaloom 2002\} and the new fully profit-sharing Japanese/international law firm partnerships, do not seem to be getting into this new policy-making game; but perhaps that remains a unique feature of US law and society anyway. 
Nonetheless, the conclusion of myself and others that significant but not overwhelming change is underway in Japan interpretation (ii)(a) - draws support from a broader recent study entitled "Beyond Continuity: Institutional Change in Advanced Political Economies". Drawing on empirical studies in Japan, Germany, France, Hungary, the UK and the US, the editors argue that "[1] equating instrumental with adaptive and reproductive minor change, and [2] major change with mostly exogenous disruption of continuity, makes excessively high demands on [3] 'real' change to be recognised as such, and tends to reduce most or all observable changes to adjustment for the purpose of stability" \{Streeck and Thelen 2005: 8\}. They are impatient with theories of path dependence that tend either, as in work on "varieties of capitalism" \{Hall and Soskice 2001\} and welfare state retrenchment \{Pierson 1994\}, to imply [1] "reproduction by adaptation", or - more rarely - [2] punctuated equilibria or "breakdown and replacement" \{Pempel 1998: 3\}. Streek and Thelen argue compellingly that theorists have not sufficiently recognised and conceptualized [3] "gradual transformation", the now much more widely observed combination of incremental change resulting in discontinuity:

Table 1 (adapted from \{Streek and Thelen 2005: 9\})

\begin{tabular}{|c|c|c|c|}
\hline \multirow{2}{*}{} & \multirow{2}{*}{} & \multicolumn{2}{|c|}{ Result of Change } \\
\cline { 2 - 4 } & Continuity & Discontinuity \\
\hline $\begin{array}{c}\text { Process of } \\
\text { Change }\end{array}$ & Incremental & $\begin{array}{c}\text { [1] Reproduction } \\
\text { by adaptation }\end{array}$ & $\begin{array}{c}{[3] \text { Gradual }} \\
\text { transformation }\end{array}$ \\
\cline { 2 - 4 } & Abrupt & $\begin{array}{c}\text { Survival and } \\
\text { return }\end{array}$ & $\begin{array}{c}\text { [2] Breakdown and } \\
\text { replacement }\end{array}$ \\
\hline
\end{tabular}


In my matrix of commentators on Japanese corporate governance, "continuity" advocates like Haley, Jacoby and Dore fall into category [1]. Strong proponents of change like The Economist fall into category [2]. Those in category [3], perceiving incremental change that nonetheless adds up to a significant transformation in Japanese corporate governance and society generally, include myself, Milhaupt and West, Vogel $\{2005\}$, and a growing majority of researchers. 22

In addition, all five modes for gradual but nonetheless transformative change, newly conceptualised by \{Streeck and Thelen: 19-30\} from their cross-national study of liberalising advanced political economies, resonate with shifts in Japan since the 1990s:

(1) "Displacement", as subordinate institutions (and related norms) slowly become more salient, can be seen in the fevered attempts by Ramseyer to prove that Japan maintained strong market-driven forms of socio-economic ordering even after World War II. Without accepting that these were the only forms, we can and should concede that some may have existed but were consciously or unconsciously downplayed. On the other hand, they still struggle to displace other forms of socio-economic ordering, evident in the "learning by monitoring" mechanisms still at work in some areas of the automobile industry (\{Nottage and Wolff 2005\}; see also \{Ahmadjian 2005\}).

(2) "Layering", whereby new elements are added onto existing institutions gradually change the status and structure of the latter, can be seen in many areas. A

\footnotetext{
${ }^{22}$ On broader changes in Japanese society, see another - aptly named - recent study: \{Kingston 2004\}. The term "gradual transformation" seems to be adapted from the earlier "Great Transformation" towards liberalized markets analysed by Karl \{Polanyi 1944\}, who pointed out also how their more destructive effects could be constrained even in modern society \{Streeck and Thelen 2005: 4\}.
} 
clear example is the superimposition of the Product Liability Law of 1994 onto the venerable Civil Code \{Nottage 2004\}. Adding post-graduate "law school" programs from 2004, as part of a raft of reforms aimed at improving civil justice for firms as well as individual citizens, also hopes to have a trickle-down effect on undergraduate legal education.23 Other examples more closely related to corporate governance include Japan's banks already differentiating more among corporate clients \{Vogel 2005\}, and the small but significant uptake already of the optional "Committee"-style board system analysed by \{Gilson and Milhaupt 2005\}.

(3) An instance of "Drift", neglecting institutional maintenance despite external change, may be the unwillingness - even compared to more liberalized Australia - to update the regulatory regime for securing the safety of general consumer goods \{Nottage $2005\}$.

(4) $\{$ Vogel 2005\} also reveals significant "Conversion" both through redeploying old institutions to new purposes (as METI adopts the mantle of more liberal reformers within government: (Elder 2003\}), and through new purposes being attached to old structures (like venture capital being incubated within corporate group subsidiaries).

(5) Finally the gradual attrition of core regular employees may be seen as "Exhaustion", involving institutions gradually withering away over time.

In short, Japan is largely following other complex industrialised democracies in "re-regulating" as it "de-regulates" \{Nottage

\footnotetext{
${ }^{23}$ I concur with the assessment by $\{$ Haley 2005a $\}$ that this initiative is unlikely to have much short-term impact. However, even here I concede some bright side, and hope that this first round of reforms can be built on to generate more thorough-going "conservative reformism" \{Nottage 2006b\}.
} 
$2005 b$, albeit probably with a different mix of the main modes for achieving such incremental but transformative change, and overall with less liberalisation than perhaps Germany and certainly France (\{Goyer 2006\}; but cf $\left\{\mathrm{O}^{\prime}\right.$ Sullivan 2005\}).

\section{Five Ways Forward: Particularly, Process Perturbations?}

Even more broadly, five caveats may be helpful in deciding whether this interim assessment is more persuasive than the other views categorised above. These points, drawing partly on similar issues arising in other comparative studies, may also be useful in carrying out or interpreting studies of corporate governance beyond Japan. Specifically, great care must be taken - and justified - in: (i) selecting timeframes, (ii) selecting countries to compare, (iii) balancing black-letter law and broader socio-economic context, (iv) reflecting on and disclosing normative preferences, and (v) giving weight to processes as well as outcomes, particularly when assessing change versus continuity.

\section{(I) Timing}

First, history matters in many ways. Analyses often seem to be influenced by when they happen to be carried out or published, for example, influenced especially by the current economic performance of the analyst's home jurisdiction and/or those compared, often linked to whether they are seen as having "good" governance or not AAronson 2005\}. In 2001, for example, after the Asian financial crisis in 1997 followed by unprecedented failure of banks and securities houses in Japan, and before the massive collapses of Enron and other firms in the US, there was a clearer tendency to see Japanese corporate governance as bad and US governance as good. This was the context, for example, for the 
theory of strong convergence on the shareholder-driven model advanced by \{Hansmann and Kraakman 2001\}.24 By contrast, from 2002 onwards, Enron and its aftermath led to skepticism about the benefits of the US approach, and hence more tendencies to perceive and acclaim ongoing divergences, in Japan and elsewhere. On the other hand, perhaps especially as new theories are deployed to explain rapidly evolving realties, several studies along such lines have drawn on rather outdated data. 25

Even if these challenges can be acknowledged and minimized, further problems arise in selecting time spans for comparisons. More objectively, for example, aspects of US corporate governance have themselves changed considerably after 2002. In particular, the Sarbanes-Oxley Act has allowed federal securities regulators to go beyond (most market-oriented) disclosure requirements, and impinge on traditionally state-based corporate law by imposing obligations as to board composition and other matters internal to the corporation \{Cioffi 2005\}. Thus, Figure 1 above (extended from HR practices to corporate governance regimes more generally) should probably have looked rather different if the comparison had run only through to around 2000. The bell curve for the US would have been even further (right) towards the market end of the spectrum than "US 2004", perhaps exacerbating a growing divergence between the US and Japan even as the latter also moves more slowly in that direction. Alternatively, more divergence may again have to be depicted in a few years from now, if $\{\mathrm{Du}$ Plessis et al 2006) correctly predict a reaction against the Act's more

\footnotetext{
${ }^{24}$ Such tendencies are related to express or implied normative preferences, discussed further in Part II(iv) below.

${ }^{25}$ Jacoby's empirical research appears to date back to around 2001. That at least was the year in which he conducted his mail survey of listed Japanese and US firms. It is unclear when exactly the interviews of several companies in similar industry sectors in both countries were carried out. A similar temporal lag is found in \{Learmount 2002: 41\}, whose fieldwork on fourteen Japanese firms was principally "carried out in 1998-99, ... with some follow-up visits in 2000". Even more strikingly, interviews by \{Hasegawa 2005\} for his 8 case studies were conducted in September 1999.
} 
interventionist approach as a result of finding that it did not prevent another likely round of corporate collapses

Figure 1 would have looked even more very different if Jacoby \{2005: 84-9\} had compared Japan and the US between 1955 and 1980, rather than 1980 and 2004, since even US firms were much more organization-oriented until the 1970s. As well as fewer differences in the distribution and means of firms in Japan and the US over that "Golden Age", there would have been fewer shifts, supporting the "strong-path-dependence" hypothesis rather than the "weak-path-dependence" he tends to find between 1980 and 2004. Even if he had focused instead on the 1980s, he might have found more evidence of "converging-divergences", with an increasing variety of firms in both countries and even a shift of the means towards each other, as some firms in the US adopted or adapted some Japanese-style management techniques. Conversely, \{Jacoby 2005: 19-20\} would have found less support for the "national-model" hypothesis, namely only Japan moving towards more market-oriented practices.

Even if we focus on recent history, say 1980-2004, this may not necessarily predict where Japan or the US will head in the next few decades - or even in the turbulent political times likely to persist for the next few years in both countries, working their ways out of different but dangerous economic circumstances. As \{Sacoby 2005: 163-73\} concedes, both countries now stand at a crossroads, although Japan may be under more pressure yet its institutions less open to normative and political perturbations. Looking back eventually over a broader historical period, say from 1980-2030, we may well find Japan to have converged somewhat on the US particularly over the late 1990s, only to diverge further after 2005 as relative economic performance picked up, even without any more shifts of the US towards market-oriented solutions. Thus, we would have to acknowledge considerable change, but not necessarily consistent convergence (see also generally \{Du Plessis 2004\}). 
On the other hand, extending the historical frame of reference has encouraged bolder commentators to detect and advocate broader world-wide convergence towards shareholder primacy in corporate governance $\{$ Hansmann and Kraakman 2001\} or, more generally, a modern liberal "horizontal society" \{Friedman 1999\}. Even \{Hall and Soskice 2001\}, proponents of "varieties of capitalism" theory that otherwise generally predicts ongoing divergences, have conceded that more "coordinated market economies" like Japan and Germany remain at risk of a one-way slide towards AngloAmerican "liberal market economies" if and when trust relationships unravel. However, as mentioned above (Part I (iii)), outright displacement does not seem to be so straightforward. More generally, \{Tanase forthcoming\} contends that the more we push for modern liberal law and society, the greater the resistance encountered as inherent contradictions emerge and community reasserts itself. Yet this begs the question of when such reactions will begin to set in, which may not be until a country like Japan has moved towards highly liberalized markets and a considerable dose of US-style "adversarial legalism" (cf \{Kagan 2001\}), judging by the gradual transformations already found in Japan and other advanced political economies. Thus, even if change does not occur uniformly, we may need to acknowledge more potential for convergence as we expand the temporal frame of reference for our analysis.

\section{(II) COUnTRIES TO COMPARE}

Secondly, especially when discussing convergence, we should be careful about our points of comparison. In particular, it is generally risky or less productive just to select two, such as Japan and the US, as this can lead to "an undue emphasis on differences" \{Aronson 2005: 43\}. This is a broader problem in all comparative law research. Adding a third jurisdiction, such as England for analyses of contract law, can uncover some important similarities between the two others, compared to this new reference point \{Nottage 2002; 2004\}. Adding Germany, common in the comparative corporate governance debate given its post-War economic performance followed by the current malaise, instead 
suggests US exceptionalism. But most commentators see somewhat more of a shift towards the US model, driven partly by the economic imperatives of EU market liberalization. Germany is certainly not becoming the US \{Cioffi 2005\} and, as just mentioned, some ruptures have appeared in the US model itself particularly after the Enron debacle securities. Nonetheless, if we were to add Germany to the spectrum in Figure 1, we would probably have to interpose similarly shaped bell curves between the pairs for Japan and the US; and with, moreover, Germany's mean shift for 1980-2004 being greater than Japan's (" $x$ " in Figure 1). That would mean "directional convergence" \{Jacoby 2005: 12\} for both Japan and Germany, towards the US model; but less "pull" on Japan (for example under the "national-model" hypothesis, if the US doesn't move), and/or stronger path dependence (even if it does). This would be an interesting result because we might fairly say that Japan is converging less, for example, but also because it may suggest that Germany may become a (hybridized) "national-model" competing with the US.

The temptation then is to further increase the countries compared. This has been characteristic of the "second generation" of comparative corporate governance scholarship, especially by those favouring economic analysis, after a first generation that simply investigated key areas of US concern (such as board composition) in individual countries \{Denis and McConnell 2005\}. Much broader cross-national research into corporate governance is also becoming popular among political scientists (eg \{Gourevitch and Shinn 2005\}). As explained in Part II $(\mathrm{v})$ below, however, there is certainly a risk in all such studies of producing "very broad and somewhat superficial conclusions, for example on issues such as the protection of minority investors, without giving any consideration to the difficult process of adapting foreign law concepts and corporate governance institutions to fit into one's own system" \{Aronson 2005: 43\}. 


\section{(III) BLACK-LETTER LAW (PERCEPTIONS OF CHANGE) VS SOCIO- ECONOMIC CONTEXT (CONTINUITIES)}

Thirdly, analysts and their audiences must be aware that in comparative legal studies there is a tendency to find quite extensive change and hence much (actual or potential) convergence when focusing on narrower (more formal) "black letter law", especially statutory provisions and case law; but to find little change and instead divergence when looking at law in broader context \{Ginsburg et al 2001; Nottage 2004\}. There is no necessary correlation between these dyads, as shown indeed by the study by \{West 2001\} demonstrating how the statutory provisions added to the Japanese Commercial Code's from Illinois law during the Occupation in 1950 have instead diverged from their source. Nonetheless, as comparative corporate governance research becomes ever broader in scope, encompassing other areas of (often still mandatory) business regulation (see eg \{Winkler 2004\}) or CSR \{Nottage 2006a\}, we need to guard against too readily concluding that regimes overall are - and will remain - fundamentally divergent and resistant to change. That may be true along some dimensions, but not along all.

\section{(IV) NORMATIVE PREFERENCES}

Fourthly, in trying to become more reflective about how and why we and others undertake comparative research like this, we need to be more honest about underlying normative influences impacting on our empirical observations. Comparative corporate governance, as a field, emerged only in the 1980s, just as culturalist approaches started to lose popularity to the economic analysis of law, initially in the US but more recently in Europe (and, to a lesser extent, Japan: \{Kozuka 2005\}). In reaction to the former's often more avowed normative slant, as well as now wellknown problems of tautology and difficulties in "proof", the economic analysis of corporate governance has tended to stress a purely empirical agenda. However, just as in other areas of economics, hidden normative agendas and the power of rhetoric are readily apparent (see eg \{Ferraro, 2005 \#172\}). Thus, Mark 
Ramseyer is not only saying that Japan has always had a competitive market economy and concomitant legal system, populated by narrowly rational economic actors. He is at least implying that it should have these features, and thus be thoroughly deregulated if there happen to be any anti-competitive remnants. 26

By contrast, despite some of his own protestations to the contrary, Haley $\{2005 a\}$ wants Japan to retain its perceived communitarian core and related broader stakeholder approach to corporate governance. 27 Thus, he both perceives and acclaims instead a more conventional regulatory paradigm. The Editor of The Economist, by contrast, wants both to uncover and to complete the unraveling of those models, in favour of the liberal models of economic and social ordering persistently trumpeted by his journal.28 Lastly, authors like myself (and perhaps Milhaupt and West) like some (more or less longstanding) features of Japanese law and society - sometimes communitarian, sometimes radically individualist - and hope that Japan can recombine them in optimal ways to meet evolving social needs and expectations.29 This approach tends therefore towards a re-regulatory paradigm. All this is not to say that we should abandon the search for empirical groundings for our normative hunches, but only to be explicit

\footnotetext{
${ }^{26}$ See $\{$ Nottage 2005b\}. This disguised normative agenda - wanting empirical studies to prove to show that markets always clear, but otherwise to deregulate to force them to do so - is also very much the approach of the (first-generation) Chicago school of (law and) economics: \{Freedman and Nottage 2006\}.

${ }^{27}$ Indeed, he wants more such elements in the US: see also \{Haley 1999\}.

${ }^{28}$ See already $\{$ Emmott 1991\}; and, urging Japan to tow the hawkish American line nowadays even on foreign policy, \{Emmott 2004\}.

${ }^{29}$ I must concede that this normative inclination may be related to a fundamental aspect of my identity: being married to a woman from Kyoto. Unlike Haley, I find it hard to acclaim all aspects of Japanese culture as reflected in my wife's behaviour and beliefs; but nor would I want to efface them or define them out of existence, as Ramseyer or Emmott seem to desire so fervently for Japan more generally.
} 
about the latter and how they may frame our empirical inquiries and conclusions.

\section{(v) Processes, not just Outcomes}

Finally, one particularly promising way to do this seems to move away from analyzing and predicting specific outcomes, and instead to focus on processes impacting on Japan's evolving corporate governance regime. As well as making us rethink how we assess change versus continuity, concentrating on processes may encourage the application of a broader range of methodologies to answer new questions. Studies should involve qualitative research as well as quantitative methods - not just the regression analyses that became almost de rigueur in analyses of commercial regulation over the 1990s, despite grave problems in generating and accessing suitably fine-grained quantitative data sets in Japan \{Brinton 2004\}. Already, we see salutary signs of impatience with applications of econometrics alone precisely in the field of comparative corporate governance \{West 2002a\}, and hence experiments in combined methods for other socio-legal studies of Japan $\{$ West 2002b\}.30

In particular, \{Gourevitch and Shinn 2005\} develop an attractive theory amenable to both multi-country quantitative analysis, and case studies including countries like Japan.31 While

\footnotetext{
${ }^{30}$ See also eg $\{$ Upham 2005\} (brilliantly pointing out the strengths and weaknesses of both Ramseyer's quantitative approach to the vexed issue of whether and why Japanese judges are truly independent in politically charged cases, and Haley's more historical and institutional approach); and (Horiuchi 2005 \} (combining quantitative and qualitative studies to explain the quite unusual phenomenon of higher voter turnout in local rather than national elections in Japan).

${ }^{31}$ \{Jacoby 2005 \} also combines both large-scale survey research with case studies of HR in firms in comparable sectors in Japan and the US; but is less interested in the process generating new corporate governance norms than in their effects on firms. \{Learmount 2002: 40\} favours a "process study", but in the sense of a mainly qualitative study of how inputs like board composition flow through to
} 
acknowledging problems still in determining causation and so on, their correlations among data sets and some limited regression analysis indicate the general usefulness of a model involving:

(a) "politics" (an independent variable comprising "preferences" of different interest groups towards governance regimes, combined with political "institutions" such as constitutional frameworks and political parties generating majoritarian versus compromise approaches); leading to

(b) "policies" (an intervening variable, reflected in "minority shareholder protections" or MSPs; and "degrees of coordination", features of Liberal Market Economies vs Coordinated Market Economics (Hall and Soskice eds 2001\}); which cause

(c) "corporate governance" variations (the dependent variable, measured by the diffusion of shareholdings).

Especially regarding (a), political preferences, they deduce three main categories of tensions and predict different corporate governance outcomes accordingly:

output variables like corporate performance, as opposed to "speculation about how governance might or should operate, based on inferences from broad statistics interpreted through different theoretical frameworks". (\{Gaston 2003\} criticizes the lack of quantitative analysis, although agreeing with Learmount's holistic approach and the especially the need for political explanations for Japan's slow change over the 1990s.) \{Hasegawa 2005\} also limits himself to a mostly qualitative analysis, based on short case studies involving interviews of four manufacturing and four non-manufacturing firms. \{Amyx 2004\} obtained a unique database of Ministry of Finance personnel records, but chose to develop detailed descriptions of the Ministry's networking into the banking sector and other agencies, rather than rigorous quantitative tests \{Grimes 2005: 395\}. 
Table 2 (adapted from \{Gourevitch and Shinn 2005: 23\})

\begin{tabular}{|c|c|c|c|}
\hline Coalitional Lineup & Winner & $\begin{array}{lr}\text { Coalition } & \text { Label } \\
\text { [country } & \text { case } \\
\text { studies] } & \end{array}$ & $\begin{array}{l}\text { Predicted } \\
\text { Outcome }\end{array}$ \\
\hline \multicolumn{4}{|l|}{ Pair A: "class conflict" } \\
\hline $\begin{array}{l}\text { Owners }(\mathrm{O})+\text { Managers } \\
(\mathrm{M}) \text { vs Workers }(\mathrm{W})\end{array}$ & $\mathrm{O}+\mathrm{M}$ & Investor [Korea] & Diffusion \\
\hline $\mathrm{O}+\mathrm{M}$ vs $\mathrm{W}$ & $\mathrm{W}$ & Labour [Sweden] & Blockholding \\
\hline \multicolumn{4}{|l|}{ Pair B: "sectoral" conflict } \\
\hline $\mathrm{O}$ vs $\mathrm{M}+\mathrm{W}$ & $M+W$ & $\begin{array}{l}\text { Corporatist } \\
\text { compromise [Japan, } \\
\text { cf Germany] }\end{array}$ & Blockholding \\
\hline O vs $M+W$ & $\mathrm{O}$ & Oligarchy [Russia] & Blockholding \\
\hline \multicolumn{4}{|l|}{ Pair C: property and voice } \\
\hline $\mathrm{O}+\mathrm{W}$ vs $\mathrm{M}$ & $\mathrm{O}+\mathrm{W}$ & Transparency [Chile] & Diffusion \\
\hline $\mathrm{O}+\mathrm{W}$ vs $\mathrm{M}$ & M & $\begin{array}{l}\text { Managerism [US, } \\
\text { France] }\end{array}$ & Diffusion \\
\hline
\end{tabular}

Gourevitch and Shinn argue that these more fine-grained coalitions and tensions, compared for example to studies like \{Roe 2003\} focusing mainly just on class conflict, better explain differences among countries and also their continuities or changes. The countries added in square brackets in the Table above are 
some that they then provide an "analytic narrative" or more qualitative explanation for, probably necessary as the model grows in complexity to better fit messy realities. Thus, Germany is seen as an "corporatist compromise", gradually unfolding towards a "transparency" coalition as workers (W) switch allegiance from managers $(\mathrm{M})$ to owners $(\mathrm{O})$ in an attempt to maintain employment in a stagnating economy. By contrast \{Gourevitch and Shinn 2005: 167\} conclude that:

"Japan is a case of a resilient corporatist compromise, grounded in a post-World War II historic compromise between managers and workers that is sustained by consensual political institutions. Since World War II there have been no broad changes in preferences towards governance, and only marginal changes in political institutions (a partial modification of electoral rules in 1996 [sic: 1994]). As predicted by the corporatist compromise model, Japanese MSPs remain relatively low, although concentration [of shareholdings] is also low. This low level of concentration also has historical roots, when Japan's blockholding zaibatsu families were wiped out by the US Occupation."

One problem with their model as applied to Japan is the disjunction between supposedly quite diffuse shareholdings (more characteristic of US-style corporate governance), and nonetheless more coordinated policies and consensus-based politics. Even so, because quantitative analysis deals in aggregates, overall the model can survive such anomalies provided other countries "fit" better. Thus, especially if we are interested in one country like Japan, we need to look carefully at the more qualitative analysis. There, it is actually arguable that the levels of MSPs and LME indicators related to "policies", as well as the complexities of "politics" especially over the 1990s, involve more US-style features than the authors concede. At the same time, shareholder diffusion has been generally seen as much lower than estimated by \{Gourevitch and Shinn 2005: 18-19\}, as indeed they concede, even though stable and cross-shareholdings have unwound considerably 
since the late 1990s \{Okabe 2002\}. Combined, these reassessments of corporate governance outcomes, policies and politics for Japan would actually bolster their overall model and conclusions across countries; but that also requires an acknowledgement of more change or convergence on the US, or perhaps a new transparency coalition as in Germany.32 Overall, therefore, their work is a very promising recent approach focusing particularly on processes generating the "rules of the game" in corporate governance, not like Milhaupt and West, mostly, so far - on how those parameters then feed back to impact on corporate behaviour.

In analyzing such processes, though, we may need to develop even more sophisticated models of contemporary politics and policymaking. Recall the suggestion by \{Gilson and Milhaupt 2005\} that making Committee-style Boards optional rather than mandatory, and even then not going as far as the US nowadays in requiring for example a majority of truly independent directors overall (cf also (Toda and McCarty 2005\}), was due to a compromise among Japan's ministries and associated interest groups, which in turn helps to explain the dispersed effects. Such views find parallels with the "public choice" explanation for "legislative failure", which hypothesizes that more tightly organized groups will tend to hijack the policy-making process in the pursuit of narrow selfinterest \{Ramseyer 1995\}.

Generally, however, public choice theory has faced powerful criticism on empirical grounds, through studies demonstrating how more diffuse groups have managed to coalesce to become

\footnotetext{
${ }^{32}$ Regarding "policies", \{Nottage 2001\} queries the ready characterization of Japan as a CME rather than a LME, as well as noting quite strong MSPs at least "on the books" in Japan. More elements of a LME also explain at least some of the results from the studies by Mark Ramseyer. Regarding "preferences", \{Gourevitch and Shinn 2005: 9\} stress that a shift away from pay-as-you-go public-sector pension schemes as a "substantial driver of new coalitional possibilities", and agree with \{Dore 2000\} that there have been few changes yet in this area in Japan. Yet they may have over-estimated this factor: their account also acknowledges few changes in this area in Germany as well.
} 
effective actors in the political process, and other work showing how legislators (and their bureaucratic agents) are often motivated by broader concerns such as ideology and the desire for respect from their peers \{Rubin 2005: 584-7\}. Prior "special interests" theory, emphasizing social elites' ability to dominate politics, is more convincing in allowing for the possibility of legislative success as well as failure. However, it ties such success to restricting political influence over policy-makers in favour of neutral and mostly bureaucratic expertise, and generally remains too narrow and deterministic in emphasizing the power of social groups and structures. "Pluralism" is more recent variant of this theory, although it sees legislative success - as well as failure - as resulting from a political process itself strongly influencing the formation of groups that struggle to dominate it. "Deliberative democracy" theory takes a step further this notion of politics as an independent social process generating its own dynamics and alliances, by suggesting that politics may also generate individual or group commitments (rather than just representing them), potentially achieving more legislative success by allowing commitments to be redefined through rational public debate. However, all four theories tend to assume a clear distinction between good public policy (and hence "legislative success" or failure) and the political process. \{Rubin 2005\} views this as increasingly untenable, descriptively and normatively, and suggests that we focus more directly on good or bad processes coupling both policy-making and politics. In particular, he agrees with empirical studies suggesting that bad processes can be associated with "conceptual failure" - generating legislation overly framed by pre-conceived ideas, derived for example from prior legal concepts (eg \{Morag-Levine 2003\}). Descriptively, and indeed normatively, this approach has its attractions for Japan but so do theories of pluralism and, perhaps especially, deliberative democracy. Certainly, compared to special interests and public choice theories, they seem a more promising way 
forward to understanding distinct shifts in Japan's policy-making processes particularly since the late 1990s.33

Even more generally, to further demonstrate the usefulness of moving away from an obsession with outcomes, even if these appear more measurable, consider Japan's recent general election \{Horiuchi et al 2005\}. Some might conclude that politics hasn't changed in Japan over the 1990s, due to the (hitherto quite conservative) LDP's huge victory in the recent election, or at least the fact that Prime Minister Koizumi's campaign agenda centred overwhelmingly on (arguably limited) reforms to the postal system.34 But others might see the glass to be half full (changing), rather than half empty (unchanged), or even to be almost full (radically changed). One way beyond this impasse is instead to focus on the process or events leading up to this election. Then it appears much clearer that Japanese politics has changed considerably. Novel elements include the dissolution of the lower House to go back directly to the citizenry on a key policy issue; the abandoning of anti-reform LDP politicians in favour of highprofile outsider ("assassin") candidates - including high-profile entrepreneur Takafumi Horie; and even the LDP's candidates' "cool biz" style of campaigning in open-necked shirts.35 \{Mulgan 2002 \} therefore seems to have been too quick to predict "Koizumi's failed revolution". Her more recent analysis of agricultural policy provides "a litmus test of political and policy change", since it exemplifies traditional political economy centred on closely aligned LDP politicians, officials and farmers. After examining "changes to electoral, bureaucratic and policymaking

\footnotetext{
${ }^{33}$ See eg \{Drysdale and Amyx eds 2003\}, \{Pharr and Schwartz eds 2003\}, \{Kingston 2004\}, \{Hook ed 2005\}, and \{Ohnesorge forthcoming\}.

${ }^{34}$ Cf $\{$ Haley 2005a\}, but also the Leader in The Economist (17 September 2005). The incipient dismantling of the postal savings system, incidentally, does largely gainsay the views of \{Maclachlan 2004\}.

${ }^{35}$ On the Horie saga, fleshing out \{Milhaupt 2005\}, see eg \{, $2005 \# 5$;, 2005 \#7;Hori, 2005 \#13;Kojima, 2005 \#16;Marquand, 2005 \#10;Sanchanta, 2005 \#8;Sanchanta, 2005 \#9;Suvendrini, 2005 \#11\}.
} 
systems, and underlying demographic, political, social and economic trends", \{Mulgan 2005: 262\} concludes that even "Japanese agricultural politics is in a state of transition as many of the features of the old model are eroding", with some changes more conducive to policy innovation although other elements of the old politics have reasserted themselves. However, \{McCormack 2005\} seems to go too far the other way in describing the latest election as part of Koizumi's plan for "the substitution of a Hayekian, neo-liberal, American way for the Keynesian doken kokka ["construction state"] redistributive, egalitarian way", advanced since the 1970s when Prime Minister Kakuei Tanaka wrested control of the government's purse strings away from Ministry of Finance bureaucrats. Instead, these political outcomes again seem to represent another gradual transformation. Perhaps more importantly, and reinforcing this sense of important change, the Koizumi administration has initiated many broader "procedural changes in the policymaking process" \{Machidori 2005\}.

\section{CONCLUSIONS AND FUTURE RESEARCH}

Ultimately, detailed and realistic analyses of corporate governance changes in Japan, which go to the heart of Japanese capitalism and socio-legal ordering more generally, must therefore go beyond how the rules of the game influence the players, and consider why and how the players redefine the rules. In other words, we must examine more closely "patterns of policy reform", as well as "patterns of corporate adjustment" \{Vogel 2005: 153-62\}. We can draw also on a rich theoretical and empirical literature combining both quantitative and qualitative analysis to show how firms in Japan and elsewhere not only respond to regulatory environments, but also attempt to reshape them - without necessarily "capturing" them, as predicted by public choice theory (\{Gunningham et al 2003\}; \{Howard-Grenville 2005\}). Studies along these lines, focusing on processes and more complex feedback loops, seem likely to demonstrate significant transformations in 
Japanese corporate and public governance, and perhaps explain better the modes of change and considerable diversity of outcomes currently in Japan. Moves in this direction, moreover, will require more interdisciplinary approaches, with those favouring legal or economic explanations engaging more with political scientists and sociologists, paralleling new tendencies in broader studies of comparative capitalism \{Coates 2005\}. In ongoing theory-building, particularly in comparative corporate governance, further insights can be drawn from lessons from the discipline of comparative law more generally, as detailed in Part II. These include closer attention to timing and timeframes for comparisons, selection of countries, balancing black-letter law and broader socio-economic context, and reflecting on - and disclosing - normative preferences.

A promising and relatively unexplored area to apply such insights is CSR, which has emerged as a major topic of debate in Japan along with narrower corporate governance issues and a loss of trust in the corporate sector following a series of corporate scandals since 2000 \{Nottage 2006a). However, analyses of CSR practices in Japanese firms are of varying reliability and quality. Again, care must be taken regarding the temporal timeframe selected \{KeizaiDoyukai 2004\}, and the countries compared \{Welford 2004\}. Because CSR is such a broad concept, seen to go beyond legal requirements, we may also expect conclusions viewing or acclaiming relatively slower change. Normative preferences - skepticism on the part of conservative economists \{Economist2005\}, approval on the part of communitarians \{Dore $2005\}$ - also need to be kept in mind. Most importantly, however, the diversity of norm-setting actors in this evolving area involving leading firms, business associations, the government, and an array of NGOs - promises to yield a rich resource further supporting the conclusion of "the gradual transformation" well underway in Japan.

More immediately, these broader theoretical points imply first the necessity for those advocating more stakeholder-focused models of corporate governance to update their understanding of its evolving 
variant in Japan. In doing so, and for even more practical purposes, it is crucial to bear in mind the typology of views outlined in Part $\mathrm{I}$, as well as the emerging consensus that significant but complex changes continue to play themselves out in Japan. 


\section{ApPendix A: CoRporate LAW Amendments SINCE 1993}

\begin{tabular}{|c|c|c|}
\hline $\begin{array}{l}\text { Year } \\
\text { (cont'd) }\end{array}$ & Main Issues & Remarks \\
\hline 1993 & $\begin{array}{l}\text { Corporate governance (limiting } \\
\text { the court filing fee for derivative } \\
\text { actions) } \\
\text { - Corporate governance } \\
\text { (introduction of a board of auditors } \\
\text { in a large company) } \\
\text { - Corporate governance (relaxing } \\
\text { the requirement for shareholders } \\
\text { to exercise their right to inspect } \\
\text { the books of the company) }\end{array}$ & $\begin{array}{l}\text { Government- } \\
\text { sponsored Bill }\end{array}$ \\
\hline 1994 & $\begin{array}{l}\text { Deregulation on stock repurchase } \\
\text { (lifting the prohibition for } \\
\text { purposes of an employee's stock } \\
\text { plan or cancellation of the stock) }\end{array}$ & $\begin{array}{l}\text { Government- } \\
\text { sponsored Bill }\end{array}$ \\
\hline $1997(1)$ & $\begin{array}{l}\text { - Introduction of the stock option } \\
\text { system } \\
\text { Deregulation of stock repurchases } \\
\text { (lifting the prohibition for } \\
\text { purposes of a stock option plan) } \\
\text { - Deregulation of stock repurchases } \\
\text { (simplifying the procedure by } \\
\text { which public corporations can } \\
\text { repurchase shares from the } \\
\text { market, or by way of a tender offer } \\
\text { also known as a TOB) }\end{array}$ & $\begin{array}{l}\text { Bill submitted } \\
\text { by } \\
\text { individual an } \\
\text { politician }\end{array}$ \\
\hline $1997(2)$ & $\begin{array}{l}\text { - Corporate restructuring (merger } \\
\text { procedures) }\end{array}$ & $\begin{array}{l}\text { Government- } \\
\text { sponsored Bill }\end{array}$ \\
\hline
\end{tabular}




\begin{tabular}{|c|c|c|}
\hline $1997(3)$ & $\begin{array}{l}\text { - Increasing penalty against the } \\
\text { company's payment to corporate } \\
\text { racketeers (sokaiya) }\end{array}$ & $\begin{array}{l}\text { Government- } \\
\text { sponsored Bill }\end{array}$ \\
\hline 1998 & $\begin{array}{l}\text { Deregulation of stock purchases } \\
\text { (expanding the available funds for } \\
\text { a simplified procedure for a public } \\
\text { corporation) }\end{array}$ & $\begin{array}{l}\text { Bill submitted } \\
\text { by } \\
\text { individual an } \\
\text { politician }\end{array}$ \\
\hline 1999 & $\begin{array}{l}\text { - Corporate } \\
\text { introduction of } \quad \text { Share-tructuring: } \\
\text { Exchange and Share-Transfer }\end{array}$ & $\begin{array}{l}\text { Government- } \\
\text { sponsored Bill }\end{array}$ \\
\hline 2000 & $\begin{array}{l}\text { - Corporate restructuring: } \\
\text { introduction of the "demerger" }\end{array}$ & $\begin{array}{l}\text { Government- } \\
\text { sponsored Bill }\end{array}$ \\
\hline $2001(1)$ & $\begin{array}{l}\text { - Deregulation of stock repurchases } \\
\text { (completely abolishing the } \\
\text { prohibition, and lifting the ban on } \\
\text { "treasury stock") } \\
\text { - Deregulation of the minimum size } \\
\text { of shares } \\
\text { - Simplifying the procedure relating } \\
\text { to the reduction of statutory } \\
\text { reserve fund }\end{array}$ & $\begin{array}{l}\text { Bill submitted } \\
\text { by an } \\
\text { individual an } \\
\text { politician }\end{array}$ \\
\hline $2001(2)$ & $\begin{array}{l}\text { - } \begin{array}{l}\text { Authorising the electronic } \\
\text { documentation of corporate } \\
\text { information }\end{array} \\
\text { - } \begin{array}{l}\text { Corporate finance (authorising the } \\
\text { company to issue call options for }\end{array} \\
\text { its shares) } \\
\text { - Simplifying the procedure for } \\
\text { stock options } \\
\text { - Corporate finance (deregulation of } \\
\text { the issuance of various kinds of } \\
\text { shares) }\end{array}$ & $\begin{array}{l}\text { Government- } \\
\text { sponsored Bill }\end{array}$ \\
\hline
\end{tabular}




\begin{tabular}{|c|c|c|}
\hline $2001(3)$ & $\begin{array}{l}\text { Corporate governance (authorising } \\
\text { the limitation of a director's } \\
\text { liability) } \\
\text { - Corporate governance (improving } \\
\text { the procedure for derivative } \\
\text { actions) }\end{array}$ & $\begin{array}{l}\text { Bill submitted } \\
\text { by } \\
\text { individual an } \\
\text { politician }\end{array}$ \\
\hline 2002 & 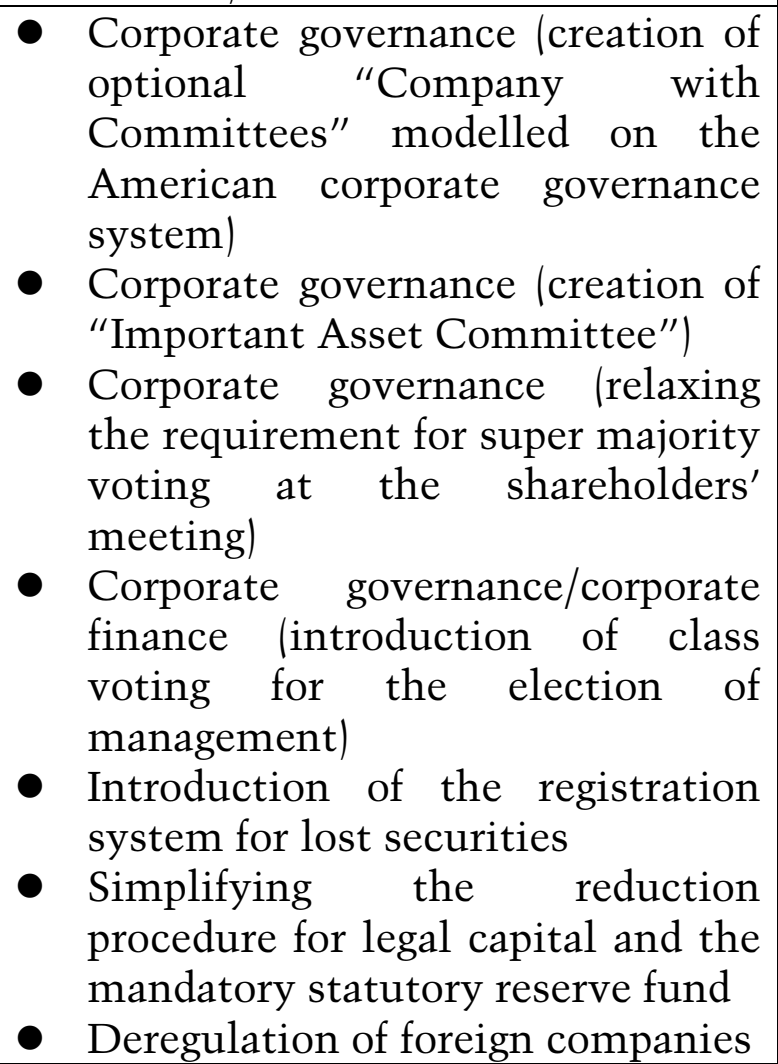 & $\begin{array}{l}\text { Government- } \\
\text { sponsored Bill }\end{array}$ \\
\hline 2003 & $\begin{array}{l}\text { Deregulation of stock repurchases } \\
\text { (simplified procedure for public } \\
\text { corporations to repurchase shares } \\
\text { from the market, or by way of a } \\
\text { tender offer often referred to as a } \\
\text { TOB) }\end{array}$ & $\begin{array}{l}\text { Bill submitted } \\
\text { by an } \\
\text { individual an } \\
\text { politician }\end{array}$ \\
\hline 2004 & $\begin{array}{l}\text { Dematerialisation of corporate } \\
\text { securities } \\
\text { - Electronic public notice system }\end{array}$ & $\begin{array}{l}\text { Government- } \\
\text { sponsored Bill }\end{array}$ \\
\hline
\end{tabular}




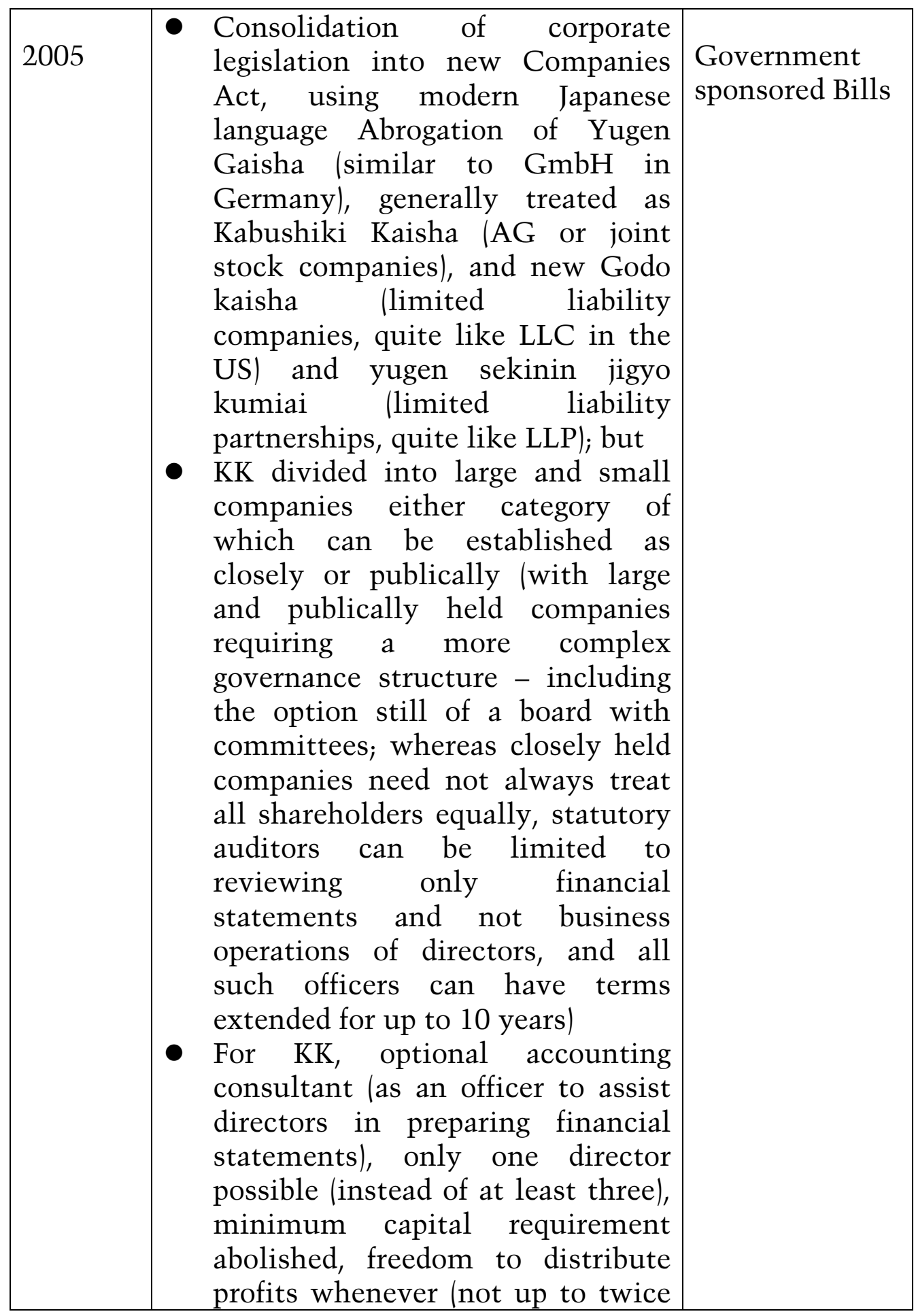




\begin{tabular}{|l|l|}
\hline per annum) \\
Tripartite mergers to allow the \\
absorbing company in merger to \\
provide cash or other assets (eg \\
parent company stocks to \\
shareholders rather than issuing \\
shares from the newly merged \\
company
\end{tabular}




\section{BIBLIOGRAPHY}

(further reading at:

www.law.usyd.edu.au/ luken/torontobiblio.pdf)

(2005). Japan Govt Maps Out Guidelines for Better Corporate Governance. Jiji Press English News Service: 1.

(2005). Livedoor Hits Fresh '05 High as Horie Decides to Run for Election. Jiji Press English News Service: 1.

(2005). Livedoor president Horie's plan to work as businessman/politician is questioned. Knight Ridder Tribune Business News: 1.

(2005). Murakami Fund spent nearly 100 bil. yen to get Hanshin stake. Knight Ridder Tribune Business News: 1.

Abe, N. and S. Shimizutani (2005). "Employment Policy and Corporate Governance: An Empirical Comparison of the Stakeholder versus the Profit-Maximisation Model." Hitotsubashi University Research Unit for Statistical Analysis in Social Sciences 92: http://www.rieti.go.jp/en/events/05091301/pdf/11_shimizutani_paper.pdf.

Acquaah-Gaisie, G. (2005). "Toward More Effective Corporate Governance Mechanisms." Australian Journal of Corporate Law 18: 1-62.

Ahmadjian, C. (2003). Changing Japanese Corporate Governance. Japan's managed globalization: adapting to the twenty-first century. U. Schaede and W. W. Grimes. Armonk, N.Y., M.E. Sharpe: 215-42.

Ahmadjian, C. and J. E. Oxley (forthcoming). "Using Hostages to Support Exchange: Dependence Balancing and Partial Equity Stakes in Japanese Automotive Supply Relationships." 
Journal of Law, Economics and Organization forthcoming: http://ssrn.com/abstract $=741207$.

Ahmadjian, C. L. and G. E. Robbins (2005). "A Clash of Capitalisms: Foreign Shareholders and Corporate Restructuring in 1990s Japan." American Sociological Review 70(3): 451.

Amyx, J. A. (2004). Japan's financial crisis: institutional rigidity and reluctant change. Princeton, NJ, Princeton University Press.

Aoki, M. (2001). Toward a comparative institutional analysis. Cambridge, Mass.; London, MIT Press.

Arikawa, Y. and H. Miyajima (2005). "Relationship Banking and Debt Choice: evidence from Japan." Corporate Governance 13(3): 408.

Aronson, B. (2005). "What Can We Learn from U.S. Corporate Governance? A Critical Analysis." University of Tokyo Journal of Law and Politics 2: 41-60.

Baum, H. and E. Takahashi (2005). Commercial and Corporate Law in Japan. History of law in Japan since 1868. W. Rèohl. Leiden, Brill: 330-401.

Blair, M. and L. Stout (2001). "Trust, Trustworthiness and the Behavioural Foundations of Corporate Law." University of Pennsylvania Law Review 149: 1735.

Brinton, M. (2003). Fact-Rich, Data-Poor: Japan as Sociologists' Heaven and Hell. Doing Fieldwork in Japan. T. C. Bestor, P. G. Steinhoff and V. Lyon-Bestor. Honolulu, University of Hawaii Press: 195-213.

Cerny, P. (2005). Governance, Globalization and the Japanese Financial System: Resistance or Restructuring. Contested 
governance in Japan: sites and issues. G. D. Hook. London, RoutledgeCurzon: 90-110.

Cioffi, J. (2005). "Corporate Governance Reform, Regulatory Politics, and the Foundations of Finance Capitalism in the United States and Germany." CLPE Research Paper 6: http://ssrn.com/abstract=830065.

Clarke, A. (2005). "Australia's Corporate Governance: Balancing Historic, Regional and Free Trade Paradigms." Australian Journal of Corporate Law 18: 103-28.

Clarke, F. L., G. W. Dean, et al. (2003). Corporate collapse: accounting, regulatory and ethical failure. Cambridge, Cambridge University Press.

Coates, D. (2005). Paradigms of Explanation. Varieties of capitalism, varieties of approaches. D. Coates. Basingstoke, Hampshire; New York, Palgrave Macmillan: 1-26.

Collett, P. and S. Hrasky (2005). "Voluntary Disclosure of Corporate Governance Practices by Listed Australian Companies." Corporate Governance 13(2): 188.

Collison, D. and Y. Kozuma (2002). "After Enron, is "Japan Inc" a better business model?" Accounting \& Business 5(9): 40.

Corbett, A. and S. Bottomley (2004). Regulating Corporate Governance. Regulating Law. C. Parker, C. Scott, N. Lacey and J. Braithwaite. Oxford, Oxford University Press: 60-81.

Dawson, C. and H. Tashiro (2005). "The Wild, Wild East." Business Week(3925): 33.

Denis, D. and J. McConnell (2005). International Corporate Governance. Corporate governance: accountability, enterprise and international comparisons. K. Keasey, M. Wright and S. Thompson. Chichester, John Wiley \& Sons: 251-83. 
Dernauer, M. (2005). "Die japanische Gesellschaftsrechtsreform des Jahres 2005/2006 [The 2005-6 Reform to Japanese Corporate Law]." Journal of Japanese Law 20: 1-40.

Dore, R. (2005). "Deviant or Different? Corporate Governance in Japan and Germany." Corporate Governance 13(3): 437.

Dore, R. P. (2000). Stock market capitalism, welfare capitalism: Japan and Germany versus the Anglo-Saxons. Oxford; New York, Oxford University Press.

Drysdale, P. and J. A. Amyx, Eds. (2003). Japanese governance: beyond Japan Inc. London, RoutledgeCurzon.

Du Plessis, J. J. (2004). "Reflections on Some Recent Corporate Governance Reforms in Germany: A Transformation of the German Aktienrecht?" Deakin Law Review 8(2): 389-404.

Du Plessis, J. J., M. Bagaric, et al. (2005). Principles of contemporary corporate governance. Melbourne, Cambridge University Press.

Economist, The (2005). "Asia: Koizumi on tour; Japan." The Economist 376(8443): 57.

Economist, The (2005). "Asia: Maehara's meagre inheritance; Japan's opposition." The Economist 376(8445): 82.

Economist, The (2005). "Special Report: Koizumi gets his way Japan's election; Japan's election." The Economist 376(8444): 24.

Economist, The (2005). "A very Japanese revolution; Japan's election." The Economist 376(8444): 12.

Economist.Intelligence.Unit (2005). "Threat of hostile takeovers hangs over Japanese companies; Better governance and more regulation the likely result, finds new Economist Intelligence Unit report." M2 Presswire: 1. 
Emmott, B. (1991). The sun also sets: the limits to Japan's economic power. New York, Simon \& Schuster.

Emmott, B. (2004). "Japan's English Lessons." Foreign Policy(140): 50.

Emmott, B. (2005). Japan Inc., RIP. Wall Street Journal: A.16.

Ferraro, F., J. Pfeffer, et al. (2005). "Economic Language and Assumptions: How Theories Can Become Self-fulfilling." Academy of Management. The Academy of Management Review 30(1): 8 .

Freedman, C. and L. Nottage (2006). "The Chicago School of Law and Economics: The Invasions by Ramseyer and Stigler." Paper presented at the ANJeL conference, "War of the Worlds in Japanese Law?" UNSW, 28 February 2006.

Friedman, L. M. (1999). The horizontal society. New Haven, Conn.; London, Yale University Press.

Fujisaki, I. (2005). "Japan's FTA Negotiations Gain Momentum." Japan Echo 32(1): 41.

Fujita, T. (2004). "Modernising Japanese Corporate Law: Ongoing Corporate Law Reform in Japan." Singapore Academy of Law Journal 16: 321-53.

Gaston, N. (2003). Review: Simon Learmount, Corporate Governance - What Can be Learned from Japan? Comparative corporate governance. J. H. Farrar. Gold Coast, Qld., Bond University Press: 385-93.

Gilson, R. and C. Milhaupt (2005). "Choice as Regulatory Reform: The Case of Japanese Corporate Governance." American Journal of Comparative Law 53: forthcoming (manuscript at http://ssrn.com/abstract=537843). 
Ginsburg, T., L. Nottage, et al. (2001). The Worlds, Vicissitudes and Futures of Japan's Law. The Multiple Worlds of Japanese Law. T. Ginsburg, L. Nottage and H. Sono, University of Victoria, BC Canada: 1-14.

Goodin, R. E. (2003). "Choose Your Capitalism?" Comparative European Politics 1(2): 203.

Gordon, J. N. and M. J. Roe, Eds. (2004). Convergence and persistence in corporate governance. New York, Cambridge University Press.

Goyer, M. (2006). Varieties of Institutional Investors and National Models of Capitalism: The Transformation of Corporate Governance in France and Germany. Complementarities, Contradictions and Conflict: Beyond the Varieties of Capitalism. B. Hancke. Oxford, Oxford University Press: forthcoming.

Grimes, W. W. (2005). "Reassessing Amakudari: What Do We Know and How Do We Know It?" Journal of Japanese Studies 31(2): 385-97.

Gunningham, N., R. A. Kagan, et al. (2003). Shades of green: business, regulation, and environment. Stanford, Calif, Stanford Law and Politics.

Haley, J. (1999). "Inside Japan's Community Controls: Lessons for America?" The Responsive Community 9(2): 22-34.

Haley, J. (2005a). "Heisei Renewal or Heisei Transformation: Are Legal Reforms Really Changing Japan." Journal of Japanese Law 19: 5-18.

Haley, J. (2005b). Japanese Perspectives, Autonomous Firms, and the Aesthetic Function of Law. Corporate Governance in Context: Corporations, State, and Markets in Europe, Japan, and the US. K. Hopt, E. Wymeersch, H. Kanda and H. Baum. Oxford, Oxford University Press: 205-14. 
Haley, J. O. (1998). The Spirit of Japanese Law. Athens/London, University of Georgia Press.

Hall, P. A. and D. Soskice (2001). Varieties of Capitalism: The Institutional Foundations of Comparative Advantage. Oxford, Oxford University Press.

Haltom, W. and M. J. McCann (2004). Distorting the law: politics, media, and the litigation crisis. Chicago, University of Chicago Press.

Hansmann, H. and R. Kraakman (2001). "The End of History for Corporate Law." Georgetown Law Journal 89: 439-68.

Hasegawa, H. (2005). The political economy of Japanese 'corporate governance': A metaphor for capitalist rationalization. Contested governance in Japan: sites and issues. G. D. Hook. London, RoutledgeCurzon: 211-32.

Hill, J. (2005). "The Persistent Debate about Convergence in Comparative Corporate Governance." Sydney Law Review 27: $743-52$.

HomukenkyuZaidan, N., Ed. (2004). Kaishahosei kara mita Funso no Kaiketsu/Kaihi [Dispute Avoidance from the Perspective of Corporate Law Structure]. Tokyo, Shoji Homu KK.

Hook, G. D., Ed. (2005). Contested governance in Japan: sites and issues. London, RoutledgeCurzon.

Hori, Y. (2005). "Horie Takafumi Takes On Japan Inc." Japan Echo 32(4): 41.

Horiuchi, Y. (2005). Institutions, incentives and electoral participation in Japan: cross-level and cross-national perspectives. London, RoutledgeCurzon.

Horiuchi, Y. and C. Braddick (2005). "The Political and Policy Implications of the 2005 General Election in Japan." 
Presentation for the AJRC and APSEG, ANU, Canberra, 26 October 2005.

Howard-Grenville, J. A. (2005). "Explaining Shades of Green: Why Do Companies Act Differently on Similar Environmental Issues?" Law \& Social Inquiry 30(3): 551.

Hutton, B. (2005). Kanebo delisting highlights flaws. Financial Times: 7.

Jackson, G. (2005). "Stakeholders under Pressure: corporate governance and labour management in Germany and Japan." Corporate Governance 13(3): 419.

Jackson, G. and A. Moerke (2005). "Continuity and Change in Corporate Governance: comparing Germany and Japan." Corporate Governance 13(3): 351.

Jacoby, S. M. (2005). The embedded corporation: corporate governance and employment relations in Japan and the United States. Princeton, NJ, Princeton University.

Jacoby, S. M., E. M. Nason, et al. (2005). "Corporate Organization in Japan and the United States: Is There Evidence of Convergence?" Social Science Japan Journal 8(1): 43.

Jacoby, S. M., E. M. Nason, et al. (2005). "The Role of the Senior HR Executive in Japan and the United States: Employment Relations, Corporate Governance, and Values." Industrial Relations 44(2): 207.

Jopson, B. (2004). Confusion still governs in corporate Japan. Financial Times: 25.

Jopson, B. (2004). Japan fund drives at governance reform. Financial Times: 23.

Jopson, B. (2004). Japan looks to tighten up regulations. Financial Times: 31 . 
Kagan, R. A. (2001). Adversarial legalism: the American way of law. Cambridge, Mass., Harvard University Press.

Kanda, H. and C. Milhaupt (2003). "Re-examining legal transplants: the director's fiduciary duty in Japanese corporate law." American Journal of Comparative Law 51: 887-901.

Kaplan, S. and J. M. Ramseyer (1996). "Those Japanese with their Disdain for Shareholders - Another Fable for Academy." Washington University Law Quarterly 32: 403.

Katz, R. (1998). Japan, the system that soured: the rise and fall of the Japanese economic miracle. Armonk, N.Y.; London, M. E. Sharpe.

Katz, R. (2003). Japanese Phoenix: the long road to economic revival. Armonk, N.Y.; London, M.E. Sharpe.

KeizaiDoyukai (2004). "Corporate Social Responsibility (CSR): Current Status and Future Challenges - CSR Survey 2003." Policy Paper: http://www.doyukai.or.jp/en/policyproposals/articles/pdf/0 40116.pdf.

Kelemen, R. D. and E. C. Sibbitt (2002). "The Americanization of Japanese Law." University of Pennsylvania Journal of International Economic Law 23: 269.

Kitagawa, T. and L. Nottage (2005). Globalization of Japanese Corporations and the Development of Corporate Legal Departments: Problems and Prospects. Raising the Bar. W. Alford. Cambridge, Mass., Harvard East Asian Legal Studies Program (distributed by Harvard University Press): forthcoming.

Kojima, A. (2005). "Horie's Brash Takeover Bid." Japan Echo 32(3): 48. 
Kojima, A. (2005). "A New Challenge to Japanese-Style Capitalism." Japan Echo 32(3): 44.

Kondo, M. (2005). "Japan's News Misfits." Japan Echo 32(1): 7.

Kozuka, S. (2005). "The Use of Economic Analysis in Japanese Commercial Law." Presentation for the ANJeL conference, "Japanese Law on Trial", University of Sydney, 23 February 2005:

http://www.law.usyd.edu.au/anjel/documents/23Feb2005C onf/Kozuka2005_EconomicAnalysis.pdf.

Learmount, S. (2002). Corporate governance: what can be learned from Japan? Oxford, Oxford University Press.

Lincoln, E. (2003). "Making Some Sense of the Japanese Economy." Japan Policy Research Institute 94:

http://www.jpri.org/publications/workingpapers/wp94.html

Lincoln, J. R. and M. L. Gerlach (2004). Japan's network economy: structure, persistence, and change. Cambridge, Cambridge University Press.

Machidori, Satoshi (2005). "The 1990s Reforms Have Transformed Japanese Politics." Japan Echo 32(3): 38.

Maclachlan, P. L. (2004). "Post office politics in modern Japan: The postmasters, iron triangles, and the limits of reform." The Journal of Japanese Studies 30(2): 281.

Marquand, R. (2005). 'Horiemon' shakes up old school politics in Japan. Christian Science Monitor: 01.

Mathews, G. and B. White, Eds. (2004). Japan's changing generations: are young people creating a new society? Japan anthropology workshop series. London, RoutledgeCurzon. 
McCormack, G. (2005). "Koizumi's Kingdom of Illusion." Japan Focus 422: http://japanfocus.org/article.asp?id=422.

Milhaupt, C. (2002). "On the (Fleeting) Existence of the Main Bank System and Other Japanese Economic Institutions." Law and Social Inquiry 27: 425.

Milhaupt, C. J. (1997). "The market for innovation in the United States and Japan: venture capital and the comparative corporate governance debate." Northwestern University Law Review 91: 865-98.

Milhaupt, C. J. (1999). "Japan's experience with deposit insurance and failing banks: implications for financial regulatory design?" Washington University Law Quarterly 77(2): 399431.

Milhaupt, C. J. (2001). "Creative norm destruction: the evolution of nonlegal rules in Japanese corporate governance." University of Pennsylvania Law Review 149(6): 2083-129.

Milhaupt, C. J. (2003). "A Lost Decade for Japanese Corporate Governance Reform? What's Changed, What Hasn't, and Why." Columbia Law and Economics Working Paper 234: http://ssrn.com/abstract=442960.

Milhaupt, C. J. (2005a). "In the Shadow of Delaware? The Rise of Hostile Takeovers in Japan." Columbia Law Review 105: 2171.

Milhaupt, C. J. (2005b). Historical Pathways of Reform: Foreign Law Transplants and Japanese Corporate Governance. Corporate Governance in Context: Corporations, State, and Markets in Europe, Japan, and the US. K. Hopt, E. Wymeersch, H. Kanda and H. Baum. Oxford, Oxford University Press: 53-72, forthcoming.

Milhaupt, C. J. and G. P. Miller (1997). "Cooperation, conflict, and convergence in Japanese finance: evidence from the "jusen" 
problem." Law \& Policy in International Business 29(1): 178.

Milhaupt, C. J. and M. D. West (2000). "The dark side of private ordering: an institutional and empirical analysis of organized crime." University of Chicago Law Review 67(1): 41-98.

Milhaupt, C. J. and M. D. West (2003a). Institutional Change and M\&A in Japan: Diversity Through Deals. Global markets, domestic institutions: corporate law and governance in a new era of cross-border deals. C. J. Milhaupt. New York; Chichester, Columbia University Press: 295-338.

Milhaupt, C. J. and M. D. West (2003b). "Law's dominion and the market for legal elites in Japan." Law and Policy in International Business 34(2): 451.

Milhaupt, C. J. and M. D. West (2004). Economic Organizations and Corporate Governance in Japan. Oxford, Oxford University Press.

Miwa, Y. and J. M. Ramseyer (2005a). Asking the Wrong Question? Changes of Governance in Historical Perspective. Corporate Governance in Context: Corporations, State, and Markets in Europe, Japan, and the US. K. Hopt, E. Wymeersch, H. Kanda and H. Baum. Oxford, Oxford University Press: 7384 , forthcoming.

Miwa, Y. and J. M. Ramseyer (2005b). The Multiple Roles of Banks? Convenient Tales from Modern Japan. Corporate Governance in Context: Corporations, State, and Markets in Europe, Japan, and the US. K. Hopt, E. Wymeersch, H. Kanda and H. Baum. Oxford, Oxford University Press: 527566 , forthcoming.

Morse, A. (2005). Regulatory Heat Drives Japan Inc. To Clean Up Act. Wall Street Journal: A.11. 
Mulgan, A. G. (2002). Japan's failed revolution: Koizumi and the politics of economic reform. Canberra, Asia Pacific Press Asia Pacific School of Economics and Management.

Mulgan, A. G. (2005). "Where Tradition Meets Change: Japan's Agricultural Politics in Transition." Journal of Japanese Studies 31(2).

Nagashima, Y. and E. A. Zaloom (2002). The Rise of the Large Japanese Business Law Firm and its Prospects for the Future. Paper presented at the Conference on "Law in Japan: A Turning Point", August 23-24, 2002, University of Washington.

Nariai, O. (2005). "Employment in Transition." Japan Echo 32(2): 38.

Nariai, O. (2005). "Testing Management Mettle." Japan Echo 32(4): 38.

Nottage, L. (2001). "Japanese corporate governance at a crossroads: variation in 'varieties of capitalism'." The North Carolina Journal of International Law \& Commercial Regulation 27(2): 255-299.

Nottage, L. (2002). "Form, Substance and Neo-Proceduralism in Comparative Contract Law: The Law in Books and the Law in Action in England, New Zealand, Japan and the U.S." Law Faculty.

Nottage, L. (2004a). "Convergence, Divergence, and the Middle Way in Unifying or Harmonising Private Law." Annual of German and European Law 1: 166-245.

Nottage, L. (2004b). Product Safety and Liability Law in Japan: From Minamata to Mad Cows. London, RoutledgeCurzon.

Nottage, L. (2005). "A Decade of Strict-liability Litigation under 
Japan's Product Liability Law of 1994." Australian Product Liability Reporter 16(1): 65-69.

Nottage, L. (2005a). "Reviewing Product Safety Regulation in Australia - and Japan?" Australian Product Liability Reporter 16(7-8): 100-6, 124-8.

Nottage, L. (2005b). Redirecting Japan's Multi-level Governance. Corporate Governance in Context: Corporations, State, and Markets in Europe, Japan, and the US. K. Hopt, E. Wymeersch, H. Kanda and H. Baum. Oxford, Oxford University Press: 571-598, forthcoming.

Nottage, L. (2006a). "Comparing Corporate Social Responsibility in Japan: Fad or Fixation?" CCH Asiawatch Newsletter January: forthcoming.

Nottage, L. (2006b). "Build Postgraduate Law Schools in Kyoto, and Will They Come - Sooner and Later?" Australian Journal of Asian Law 7: forthcoming.

Nottage, L. and L. Wolff (2000-5). Japan. Doing Business in Asia. Singapore, CCH Pte Ltd (looseleaf).

Nottage, L. and L. Wolff (2005). Corporate Governance and Law Reform in Japan: From the Lost Decade to the End of History? Japanese Management: In Search of a New Balance Between Continuity and Change. R. Haak and M. Pudelko. New York, Palgrave Macmillan: forthcoming.

O'Sullivan, M. (2005). Analysing Change in Corporate Governance: The Example of France. Corporate governance: accountability, enterprise and international comparisons. K. Keasey, M. Wright and S. Thompson. Chichester, John Wiley \& Sons: 351-87.

Ohnesorge, J. (forthcoming). Politics, Ideology and Legal System Reform in Northeast Asia. [Working Title]. C. Antons. Routledge Curzon. 
Okabe, M. (2002). Cross shareholdings in Japan: a new unified perspective of the economic system. Cheltenham, U.K., Edward Elgar Pub.

Okazaki, T. (2004). "Holding Company and Bank: An Historical Comparative Perspective on Corporate Governance in Japan." Seoul Journal of Economics 17(3): 383-402.

Pempel, T. J. (1998). Regime shift: comparative dynamics of the Japanese political economy. Ithaca, NY, Cornell University Press.

Pilling, D. (2005). "FT.com site: Livedoor president to run for parliament." FT.com: 1.

Pinto, A. (2005). "Globalization and the Study of Comparative Corporate Governance." Wisconsin International Law Journal 2005: forthcoming.

Pistor, K., Y. Keinan, et al. (2003a). "The evolution of corporate law: A cross-country comparison." Corporate Practice Commentator 45(2): 401.

Pistor, K., Y. Keinan, et al. (2003b). "Innovation in corporate law." Journal of Comparative Economics 31(4): 676.

Ramseyer, J. M. (1995). "Public Choice." Coase Lecture Series: http://www.law.uchicago.edu/Lawecon/WkngPprs_2650/34.Ramseyer.pdf.

Ramseyer, J. M. and M. Nakazato (1999). Japanese law: an economic approach. Chicago, University of Chicago Press.

Roe, M. J. (2003). Political determinants of corporate governance: political context, corporate impact. Oxford, Oxford University Press.

Rubin, E. (2005). "The Conceptual Explanation for Legislative Failure." Law \& Social Inquiry 30(3): 583-606. 
Saito, T. and Y. Genda (2005). "NEETs: Young People Who Fear Society's Gaze." Japan Echo 32(1): 14.

Sanchanta, M. (2004). Shareholders heard, but not always heeded. Financial Times: 23.

Sanchanta, M. (2005). Japan's web bloggers silent amid election cacophony. Financial Times: 4.

Sanchanta, M. (2005). Japanese pension funds embrace corporate reform: Under pressure to boost returns, funds are holding boards to account, writes Mariko Sanchanta. Financial Times: 28.

Sanchanta, M. (2005). Koizumi's 'assassins' fail to eliminate postal rebels LDP Strategy. Financial Times: 12.

Sanchanta, M. (2005). Shareholders wary of contrived defences: ItoYokado's holding company move, that will include SevenEleven, has added to shareholders' worries in Japan, says Mariko Sanchanta. Financial Times: 26.

Sapsford, J. and M. Fackler (2005). Directors' Roles Shift in Japan; Sony Shake-Up May Signal Trend Toward Board Independence. Wall Street Journal: A.15.

Sarra, J. and M. Nakahigashi (2002). "Balancing social and corporate culture in the global economy: the evolution of Japanese corporate culture and norms." Law and Policy 24: 299-354.

Seike, A. (2005). "Readying Society for an Old-Aged Workforce." Japan Echo 32(2): 42.

Seki, T. (2005). "Legal Reform and Shareholder Activism by Institutional Investors in Japan." Corporate Governance 13(3): 377. 
Stafford, P. (2005). Shareholder power wins support Corporate Governance: Philip Stafford looks at how boardrooms are coming to terms with an unusual force. Financial Times: 3.

Streeck, W. and K. A. Thelen, Eds. (2005). Beyond continuity: institutional change in advanced political economies. New York, Oxford University Press.

Streeck, W. and K. A. Thelen (2005). Introduction. Beyond continuity: institutional change in advanced political economies. W. Streeck and K. A. Thelen. New York, Oxford University Press: 1-38.

Takahashi, E. and T. Sakamoto (2004). "Japanese Corporate Law: Important Cases in 2002 and 2003." Journal of Japanese Law 17: $241-53$.

Takahashi, E. and M. Shimizu (2005). "The Future of Japanese Corporate Governance: The 2005 Reform." Journal of Japanese Law 19: 35-68.

Tanase, T. (2005). "Nihonjin no Kenrikan/Keibatsu Ishiki to Jiyushugiteki Hochitsujo [Japanese Conceptions of Rights and Attitudes towards Punishment, and Liberal Legal Order]." Hogaku Ronso 157(4/5): 1-32/1-35.

Tanase, T. (forthcoming). The Hermeneutics of Japanese Law: Community and Modernity (8 chapter book manuscript)

Tatsuta, M. (2005). Ongoing Modernization of Japanese Company Law. Corporate Governance in Context: Corporations, State, and Markets in Europe, Japan, and the US. K. Hopt, E. Wymeersch, H. Kanda and H. Baum. Oxford, Oxford University Press: 191-204, forthcoming.

Tett, G. (2004). Saving the sun: A Wall Street gamble to rescue Japan from its trillion-dollar meltdown. London, Random House Business. 
Thelen, K. A. (2004). How institutions evolve: the political economy of skills in Germany, Britain, the United States, and Japan. Cambridge; New York, Cambridge University Press.

Toda, M. and W. McCarty (2005). "Corporate Governance Changes in the Two Largest Economies: What's Happening in the U.S. and Japan?" Syracuse Journal of International Law and Commerce 32(2): 189.

Vogel, S. (2005). [Japan]. Beyond continuity: institutional change in advanced political economies. W. Streeck and K. A. Thelen. New York, Oxford University Press: 148.

von Nessen, P. (1999). "The Americanization of Australian Corporate Law." Syracuse Journal of International Law and Commerce 26: 239-66.

Wan, W., R. Hoskisson, et al. (2005). International Corporate Governance. Corporate governance: accountability, enterprise and international comparisons. K. Keasey, M. Wright and S. Thompson. Chichester, John Wiley \& Sons: 327-50.

Welford, R. (2005). "Corporate Social Responsibility in Europe, North America and Asia: 2004 Survey Results." The Journal of Corporate Citizenship(17): 33.

Werder, A. v., T. Talaulican, et al. (2005). "Compliance with the German Corporate Governance Code: An Empirical Analysis of the Compliance Statements by German Listed Companies." Corporate Governance 13(2): 179.

West, M. D. (1994). "The pricing of shareholder derivative actions in Japan and the United States." Northwestern University Law Review 88: 1436-507.

West, M. D. (1999). "Information, institutions, and extortion in Japan and the United States: making sense of sokaiya 
racketeers." Northwestern University Law Review 93(3): 767-817.

West, M. D. (2001). "The puzzling divergence of corporate law: evidence and explanations from Japan and the United States." University of Pennsylvania Law Review 150(2): $527-$ 601.

West, M. D. (2001). "Why shareholders sue: the evidence from Japan." Journal of Legal Studies 30(2 (pt1)): 351-82.

West, M. D. (2002). "Resolution of karaoke disputes: the calculus of institutions and social capital." Journal of Japanese Studies 28: 301.

West, M. D. (2002a). "Legal Determinants of World Cup Success." Michigan Law and Economics Research Paper 02-009: http://ssrn.com/abstract=318940.

Winkler, A. (2004). "Corporate law or the law of business? Stakeholders and corporate governance at the end of history." Law and Contemporary Problems 67(4): 109.

Wiseman, P. (2004). Funds bring American ideas to Japanese business; Calpers backs 2 that seek corporate reform. USA Today: B.10.

Zumbansen, P. (2004). "European Corporate Law and National Divergences: The Case of Takeover Regulation." Washington University Global Studies Law Review 3: 86786.driven.] 